\title{
Chemical Constituents from the Rhizomes of Smilax glabra and Their Antimicrobial Activity
}

\author{
Shuo Xu ${ }^{1}$, Ming-Ying Shang ${ }^{1}{ }^{*}$, Guang-Xue Liu ${ }^{1}$, Feng Xu ${ }^{1}$, Xuan Wang ${ }^{1}$, \\ Cheng-Chao Shou ${ }^{2}$ and Shao-Qing Cai ${ }^{1, *}$
}

1 State Key Laboratory of Natural and Biomimetic Drugs, School of Pharmaceutical Sciences, Peking University, No. 38, Xueyuan Road, Beijing 100191, China;

E-Mails: jessica06250917@126.com (S.X.); guangx1@bjmu.edu.cn (G.-X.L.); xufeng_pharm@163.com (F.X.); xuanwang6818@bjmu.edu.cn (X.W.)

2 Key Laboratory of Carcinogenesis and Translational Research (Ministry of Education), Department of Biochemistry and Molecular Biology, Peking University Cancer Hospital \& Institute, No. 52 Fucheng Road, Beijing 100142, China; E-Mail: cshou@vip.sina.com

* Authors to whom correspondence should be addressed; E-Mails: myshang@bjmu.edu.cn (M.-Y.S.); sqcai@bjmu.edu.cn (S.-Q.C.); Tel./Fax: +86-10-8280-2534 (M.-Y.S.);

Tel./Fax: +86-10-8280-1693 (S.-Q.C.).

Received: 10 April 2013; in revised form: 24 April 2013 / Accepted: 2 May 2013 /

Published: 8 May 2013

\begin{abstract}
Six new phenolic compounds, named smiglabrone A (1), smiglabrone B (2), smilachromanone (3), smiglastilbene (4), smiglactone (5), smiglabrol (6), together with fifty-seven known ones 7-63 were isolated from the rhizomes of Smilax glabra. Their structures were elucidated on the basis of extensive spectroscopic analyses, as well as by comparison with literature data. Twenty-seven of these compounds were obtained from and identified in the genus Smilax for the first time. The absolute configuration of $(2 S)-1,2-O-$ di-trans-p-coumaroylglycerol (43) was determined for the first time using the excitoncoupled circular dichroism (ECCD) method. Thirty isolated compounds were evaluated for their antimicrobial activity against three Gram-negative bacteria, three Gram-positive bacteria and one fungus, and the corresponding structure-activity relationships were also discussed. Eighteen compounds were found to be antimicrobial against the microorganisms tested and the minimum inhibitory concentrations (MIC) were in the range of 0.0794-3.09 mM. Among them, compound 1 showed antimicrobial activity against Canidia albicans with MIC value of $0.146 \mathrm{mM}$, which was stronger than cinchonain Ia with an MIC of $0.332 \mathrm{mM}$. Compounds 3 and $\mathbf{4}$ exhibited inhibitory activity against
\end{abstract}


Staphylococcus aureus with MIC values of 0.303 and $0.205 \mathrm{mM}$, respectively. The results indicated that these antimicrobial constituents of this crude drug might be responsible for its clinical antimicrobial effect.

Keywords: Smilax glabra; phenylpropanoid-substituted epicatechin; homoisoflavanone; stilbenes; antimicrobial activity

\section{Introduction}

The genus Smilax (Liliaceae) includes about 300 species and is widely distributed in tropical and temperate regions throughout the World, especially in East Asia and North America [1]. Many of them have been long used as medicinal herbs, especially in China as Traditional Chinese Medicines (TCM) [1]. As one of the most popular and important TCM in the genus, Smilax glabra Roxb., is an evergreen vine widely distributed in southern China [2]. The rhizomes of S. glabra, known as Tufuling in China, are used as a TCM for detoxication, clearing heat, relieving dampness and easing joint movement $[2,3]$. Modern pharmacological research showed that the S. glabra extracts possessed anti-inflammatory, immunomodulatory, protective against hepatocyte damage and anti-tumor effects [4,5]. The 95\% ethanol and ethyl acetate extracts of this herb were reported to show antibacterial activity in vitro using the K-B paper dispersion and the broth dilution methods [6]. Previous phytochemical investigations have shown that the main constituents in the rhizomes of $S$. glabra include flavonoids, phenylpropanoids and phenolic acids [2,5]. Astilbin was thought to be the main bioactive constituent and reported to have antibacterial, antitumor, anti-inflammatory, selective immunosuppressive and antioxidant properties [7,8]. The four other constituents, including three stereoisomers of astilbin named neoastilbin, isoastilbin and neoisoastilbin, as well as their aglycon taxifolin, also displayed antibacterial and antitumor activities [8].

It have been demonstrated that the rhizomes of $S$. glabra can be used as a TCM for numerous conditions, including acute bacterial dysentery, colds, cancer, nephritis, mercury poisoning, rheumatoid arthritis, colitis and skin disorders [2,3,9]. Many of the conditions are of infective etiology, which may point to the antimicrobial efficacy of this crude drug. Previous pharmacological investigations indicated that the rhizomes of $S$. glabra had antibacterial activity. However, except for several flavanones mentioned above, little is known about the chemical constituents that contribute to its antimicrobial activity. To clarify the structures and bioactivities of uncharacterized constituents, we carried out further chemical investigation on the rhizomes of $S$. glabra. A comprehensive chromatographic separation of the bioactive ethyl acetate and $n$-butanol fractions resulted in the isolation of sixty-three constituents (Figures 1 and 2), including six new compounds 1-6. Compounds $\mathbf{1}$ and $\mathbf{2}$ are two new phenylpropanoid-substituted epicatechins and their structures are closely related to cinchonain Ia, that possesses antioxidant [10], antifungal and antiviral activities [11]. Compounds $\mathbf{3}$, 4, 5 and 6 are the corresponding homoisoflavanone, stilbene, lactone and benzene ring derivatives, respectively. Their structures were elucidated based on $1 \mathrm{D}$ and $2 \mathrm{D}$ NMR, CD, IR, and MS spectroscopic data, along with comparison with literature data. In an effort to determine the active principles of $S$. glabra, and as a part of our research for new source of antimicrobial compounds, 
in vitro tests were performed to determine the inhibitory activity of extracts and compounds from this species against three Gram-negative bacteria: Escherichia coli, Pseudomonas aeruginosa PA01 and Kiebsiella pneumonia (clinical isolate), three Gram-positive bacteria: methicillin-resistant Staphylococcus aureus (clinical isolate), Staphylococcus aureus ATCC6538 and Enterococcus faecalis and one fungus, Canidia albicans SC5314. In this paper, we report the isolation and structure elucidation of the new compounds and the antimicrobial activity of most of the isolated constituents.

Figure 1. Chemical structures of compounds 1-6.

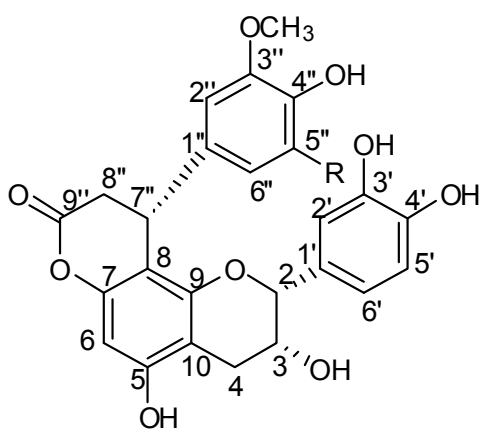

$1 \mathrm{R}=\mathrm{OCH}_{3}$

$2 \mathrm{R}=\mathrm{H}$<smiles>COc1cc2c(c(O)c1C)C(=O)[C@](O)(Cc1ccc(O)cc1)CO2</smiles>

3

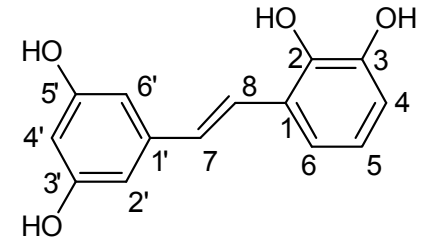

4<smiles>Cc1ccc(O)c(C)c1C1OC(=O)CC1C(C)C</smiles>

5<smiles>COC(c1ccc(O)cc1)C(O)c1cc(O)cc(O)c1</smiles>

6

Figure 2. Chemical structures of compounds 7-23, 28-45, 49-52 and 62.<smiles>[R6]Oc1cc(O)c2c(c1)OC(c1ccc(O)c([R])c1)C([R])C2=O</smiles>

$7 \mathrm{R}_{1}=\mathrm{R}_{3}=\mathrm{OH}, \mathrm{R}_{2}=\mathrm{H} 2 R, 3 R$

$8 \mathrm{R}_{1}=\mathrm{R}_{2}=\mathrm{R}_{3}=\mathrm{H}, 2 \mathrm{~S}$

$9 \mathrm{R}_{1}=\mathrm{OH}, \mathrm{R}_{2}=\mathrm{R}_{3}=\mathrm{H} 2 \mathrm{R}, 3 R$

$10 \mathrm{R}_{1}=\mathrm{R}_{3}=\mathrm{H}, \mathrm{R}_{2}=\mathrm{CH}_{3} 2 \mathrm{~S}$

$11 \mathrm{R}_{1}=\mathrm{ORha}, \mathrm{R}_{2}=\mathrm{H}, \mathrm{R}_{3}=\mathrm{OH} 2 R$, $3 \mathrm{~S}$

$12 \mathrm{R}_{1}=\mathrm{ORha}, \mathrm{R}_{2}=\mathrm{H}, \mathrm{R}_{3}=\mathrm{OH} 2 \mathrm{R}, 3 R$

$13 \mathrm{R}_{1}=\mathrm{ORha}, \mathrm{R}_{2}=\mathrm{H}, \mathrm{R}_{3}=\mathrm{OH} 2 \mathrm{~S}, 3 \mathrm{~S}$

$14 \mathrm{R}_{1}=\mathrm{ORha}, \mathrm{R}_{2}=\mathrm{H}, \mathrm{R}_{3}=\mathrm{OH} 2 \mathrm{~S}, 3 R$

$15 \mathrm{R}_{1}=\mathrm{ORha}, \mathrm{R}_{2}=\mathrm{R}_{3}=\mathrm{H} 2 R, 3 R$

$16 \mathrm{R}_{1}=\mathrm{OGlc}, \mathrm{R}_{2}=\mathrm{R}_{3}=\mathrm{H} 2 R, 3 R$

$17 \mathrm{R}_{1}=\mathrm{OH}, \mathrm{R}_{2}=\mathrm{Glc}, \mathrm{R}_{3}=\mathrm{H} 2 R, 3 R$

$18 \mathrm{R}_{1}=\mathrm{OH}, \mathrm{R}_{2}=\mathrm{H}, \mathrm{R}_{3}=\mathrm{OGlc} 2 R, 3 R$

$19 \mathrm{R}_{1}=\mathrm{OGlc}, \mathrm{R}_{2}=\mathrm{H}, \mathrm{R}_{3}=\mathrm{OH} 2 \mathrm{~S}, 3 \mathrm{~S}$<smiles>Oc1cc(O)c2c(c1)O[C@H](c1ccc(O)c(O)c1)[C@H](O)C2</smiles>

20<smiles>O=C1C[C@H](c2ccc(O)c(O)c2)c2c(cc(O)c3c2O[C@H](c2ccc(O)c(O)c2)[C@@H](O)C3)O1</smiles>

22<smiles>Oc1cc(O)c2c(c1)O[C@H](c1ccc(O)c(O)c1)[C@H](O)C2</smiles>

21<smiles>O=C1C[C@H](c2ccc(O)c(O)c2)c2c(cc(O)c3c2O[C@H](c2ccc(O)c(O)c2)[C@H](O)C3)O1</smiles>

23 
Figure 2. Cont.<smiles>COc1c(O)ccc(C(=O)/C=C/c2ccc(O)cc2)c1O</smiles>

28<smiles>[R]c1cc(/C=C2\Oc3cc(O)cc(O)c3C2=O)ccc1O</smiles>

$29 \mathrm{R}=\mathrm{H}$

$30 \mathrm{R}=\mathrm{OH}$<smiles>COc1cc([C@H]2OC(=O)[C@@H]3[C@H](c4ccc(O)c(OC)c4)OC[C@H]23)ccc1O</smiles>

32<smiles>COc1cc([C@H]2c3c(O)cc(O)cc3[C@H]3[C@H]2CO[C@H]3c2ccc(O)c(O)c2)cc(OC)c1O</smiles>

35<smiles>COc1cc(C(O)C(CO)C(CO)C(O)c2cc(OC)c(O)c(OC)c2)cc(OC)c1O</smiles>

33<smiles>COc1cc(CC(CO)[C@H](CO)Cc2ccc(O)c(OC)c2)ccc1O</smiles>

31<smiles>O=C(/C=C/c1ccc(O)c(O)c1)O[C@@H]1CC(C(=O)O)=C[C@@H](O)C1O</smiles><smiles>O=C(/C=C/c1ccc(O)cc1)OC[C@H](CO)OC(=O)/C=C/c1ccc(O)cc1</smiles>

43<smiles>[R20]Oc1cc(C(=O)O)cc([R])c1[R20]</smiles>

$50 \mathrm{R}_{1}=\mathrm{CH}_{3}, \mathrm{R}_{2}=\mathrm{Glc}, \mathrm{R}_{3}=\mathrm{OCH}_{3}$

$51 R_{1}=R_{2}=R_{3}=H$

$52 \mathrm{R}_{1}=\mathrm{CH}_{3}, \mathrm{R}_{2}=\mathrm{H}, \mathrm{R}_{3}=\mathrm{OH}$<smiles>COc1cc(C2Oc3cc(/C=C/c4cc(O)cc(O)c4)ccc3O[C@@H]2CO)cc(OC)c1O</smiles>

36<smiles>[R20]Oc1cc(O)cc(/C=C/c2ccc(O)c([R2])c2)c1</smiles>

$37 \mathrm{R}_{1}=\mathrm{R}_{2}=\mathrm{H}$

$38 \mathrm{R}_{1}=\mathrm{Glc}, \mathrm{R}_{2}=\mathrm{H}$

$39 \mathrm{R}_{1}=\mathrm{H}, \mathrm{R}_{2}=\mathrm{OH}$
34<smiles>COc1cc(C2c3c(cc(OC)c(O)c3O)CC(CO)C2CO)cc(OC)c1O</smiles> 


\section{Results and Discussion}

\subsection{Structural Elucidation of the New Compounds}

Compound 1 (Figure 1) was obtained as a pale yellow solid. The molecular formula of compound $\mathbf{1}$, $\mathrm{C}_{26} \mathrm{H}_{24} \mathrm{O}_{10}$, was concluded from its HRESIMS, which showed a quasi-molecular ion peak at $\mathrm{m} / \mathrm{z}$ $495.1299[\mathrm{M}-\mathrm{H}]^{-}$(calcd. for $\mathrm{C}_{26} \mathrm{H}_{23} \mathrm{O}_{10} 495.1291$ ) in the negative ion mode. Its IR spectrum showed absoptions due to hydroxyl $\left(3,452 \mathrm{~cm}^{-1}\right)$ and carbonyl $\left(1,751 \mathrm{~cm}^{-1}\right)$ groups. In the UV spectrum, absorption maxima at 202, 230 and $280 \mathrm{~nm}$ were observed. The ${ }^{1} \mathrm{H}-\mathrm{NMR}$ and ${ }^{13} \mathrm{C}-\mathrm{NMR}$ spectra (Table 1) showed one ABX coupling system at $\delta 7.06(1 \mathrm{H}, \mathrm{d}, J=1.9 \mathrm{~Hz}), \delta 6.79(1 \mathrm{H}, \mathrm{d}, J=8.1 \mathrm{~Hz})$ and $\delta 6.84$ $(1 \mathrm{H}, \mathrm{dd}, J=8.1,1.9 \mathrm{~Hz})$, two geminal coupling proton signals at $\delta 2.92(1 \mathrm{H}, \mathrm{dd}, J=17.2,4.5 \mathrm{~Hz})$ and $\delta 2.85(1 \mathrm{H}, \mathrm{dd}, J=17.2,1.7 \mathrm{~Hz})$, and three aliphatic carbon signals at $\delta 79.8(\mathrm{C}-2), \delta 66.8(\mathrm{C}-3), \delta$ 29.8 (C-4). These findings revealed the presence of an epicatechin unit. In the ${ }^{1} \mathrm{H}-\mathrm{NMR}$ spectrum of $\mathbf{1}$, an aromatic proton singlet at $\delta 6.20$ was observed, which suggested substitution at the 6- or 8-position of the A-ring. The presence of one symmetrical 1,3,4,5-tetrasubstituted phenyl group was deduced from the signal at $\delta 6.43(2 \mathrm{H}, \mathrm{s})$. The ${ }^{1} \mathrm{H}-\mathrm{NMR}$ spectrum also indicated the presence of two methoxy groups at $\delta 3.59(6 \mathrm{H}, \mathrm{s})$, a methine proton at $\delta 4.60(1 \mathrm{H}$, br.d, $J=6.3 \mathrm{~Hz})$, and the methylene protons at $\delta 3.12(1 \mathrm{H}, \mathrm{dd}, J=15.9,7.5 \mathrm{~Hz})$ and $\delta 2.91(1 \mathrm{H}, \mathrm{dd}, J=15.9,1.5 \mathrm{~Hz})$. In addition, resonances attributable to a methine carbon at $\delta 36.2$ and a methylene carbon at $\delta 37.5$ were observed. The HMBC spectrum (Figure 3) showed correlations from H-2" to C-7" ( $\delta$ 36.2), H-7" to C-1" $(\delta$ 135.2) and H-8" to $\mathrm{C}-9$ " $(\delta$ 171.0), indicating the presence of a phenylpropanoid unit. In the HMBC spectrum, correlations of $\mathrm{H}-8^{\prime \prime}$ with $\mathrm{C}-8(\delta$ 106.2), C-1" $(\delta$ 135.2) and C-9" $(\delta$ 171.0) indicated that the phenylpropanoid unit was attached to the $\mathrm{C}-8$ position of the epicatechin, which was further confirmed by the diagnostic ${ }^{13} \mathrm{C}-\mathrm{NMR}$ resonances for the C-10, C-6 and C-8 carbons at $\delta 105.4,96.3$ and 106.1. It has been established that in the NMR spectra the position of the $\mathrm{C}-10$ chemical shift is distinctive for the location of the lactone function in the A-ring. The C-8 location has the C-10 chemical shift downfield $(\delta$ 105) relative to the C-6 regioisomer $(\delta$ 100) [12]. For compound $\mathbf{1}$, the C-10 resonance was in accordance with those of C-8 phenylpropanoid-substituted epicatechins. Furthermore, the ${ }^{13} \mathrm{C}-\mathrm{NMR}$ resonance at $\delta 171.0\left(\mathrm{C}-9^{\prime \prime}\right)$ indicated that the phenylpropanoid unit was fused to the $\mathrm{OH}$ group at $\mathrm{C}-7$ of the A-ring of the epicatechin unit through an ester linkage. The HMBC correlation between the methoxy protons at $\delta 3.59(6 \mathrm{H}, \mathrm{s})$ and $\delta 149.2\left(\mathrm{C}-3^{\prime \prime}, 5^{\prime \prime}\right)$ confirmed the methoxy groups were linked to C-3", 5". Thus, compound $\mathbf{1}$ was very similar to cinchonain Ia, previously isolated from the bark of Cinchona succirubra, but with additional $O$-methyl groups [13]. The absolute configuration of C-7" was defined based on the CD spectrum, which showed negative Cotton effects at 235 and $283 \mathrm{~nm}$ and a positive Cotton effect at $259 \mathrm{~nm}$. Hence, the absolute configuration of C-7" was determined to be $R$ [13]. Consequently, the structure of 1 was elucidated as epicatechin-(7,8-bc)-4 $\alpha$-(4-hydroxy-3,5-dimethoxyphenyl)-dihydro-2(3H)-pyranone, and was trivially named smiglabrone A. 
Table 1. ${ }^{1} \mathrm{H}-\mathrm{NMR}(600 \mathrm{MHz})$ and ${ }^{13} \mathrm{C}-\mathrm{NMR}(150 \mathrm{MHz})$ spectra data of compounds 1 and 2 (in $\mathrm{CD}_{3} \mathrm{OD}, J$ in $\mathrm{Hz}, \delta$ in ppm).

\begin{tabular}{|c|c|c|c|c|}
\hline \multirow{2}{*}{ Position } & \multicolumn{2}{|l|}{1} & \multicolumn{2}{|l|}{2} \\
\hline & $\delta_{\mathrm{H}}(J$ in $\mathrm{Hz})$ & $\delta_{\mathrm{C}}$ & $\delta_{\mathrm{H}}(J$ in $\mathrm{Hz})$ & $\delta_{\mathrm{C}}$ \\
\hline 2 & $4.81(1 \mathrm{H}, \mathrm{s})$ & 79.8 & $4.82(1 \mathrm{H}, \mathrm{s})$ & 79.8 \\
\hline 3 & $4.26(1 \mathrm{H}, \mathrm{m})$ & 66.8 & $4.25(1 \mathrm{H}, \mathrm{m})$ & 66.7 \\
\hline \multirow[t]{2}{*}{4} & $2.85(1 \mathrm{H}, \mathrm{dd}, J=17.2,1.7)$ & 29.8 & $2.85(1 \mathrm{H}, \mathrm{dd}, J=17.2,2.0)$ & 29.7 \\
\hline & $2.92(1 \mathrm{H}, \mathrm{dd}, J=17.2,4.5)$ & & $2.92(1 \mathrm{H}, \mathrm{dd}, J=7.2,4.4)$ & \\
\hline 5 & - & 157.4 & - & 157.4 \\
\hline 6 & $6.20(1 \mathrm{H}, \mathrm{s})$ & 96.3 & $6.19(1 \mathrm{H}, \mathrm{s})$ & 96.3 \\
\hline 7 & - & 151.6 & - & 151.7 \\
\hline 8 & - & 106.2 & - & 106.2 \\
\hline 9 & - & 153.6 & - & 153.5 \\
\hline 10 & - & 105.4 & - & 105.3 \\
\hline $1^{\prime}$ & - & 132.0 & - & 132.0 \\
\hline $2^{\prime}$ & $7.06(1 \mathrm{H}, \mathrm{d}, J=1.9)$ & 115.1 & $7.03(1 \mathrm{H}, \mathrm{d}, J=1.8)$ & 115.1 \\
\hline $3^{\prime}$ & - & 146.2 & - & 146.1 \\
\hline $4^{\prime}$ & - & 145.9 & - & 145.8 \\
\hline $5^{\prime}$ & $6.79(1 \mathrm{H}, \mathrm{d}, J=8.1)$ & 116.1 & $6.781(1 \mathrm{H}, \mathrm{d}, J=8.2)$ & 116.0 \\
\hline $6^{\prime}$ & $6.84(1 \mathrm{H}, \mathrm{dd}, J=8.1,1.9)$ & 119.1 & $6.83(1 \mathrm{H}, \mathrm{dd}, J=8.2,1.8)$ & 119.1 \\
\hline $1^{\prime \prime}$ & - & 135.2 & - & 135.8 \\
\hline $2^{\prime \prime}$ & $6.43(1 \mathrm{H}, \mathrm{s})$ & 105.0 & $6.776(1 \mathrm{H}, \mathrm{d}, J=2.0)$ & 112.2 \\
\hline $3^{\prime \prime}$ & - & 149.2 & - & 148.8 \\
\hline $4^{\prime \prime}$ & - & 135.1 & - & 146.3 \\
\hline $5^{\prime \prime}$ & - & 149.2 & $6.62(1 \mathrm{H}, \mathrm{d}, J=8.2)$ & 116.2 \\
\hline $6^{\prime \prime}$ & $6.43(1 \mathrm{H}, \mathrm{s})$ & 105.0 & $6.50(1 \mathrm{H}, \mathrm{dd}, J=8.2,2.0)$ & 119.4 \\
\hline $7 "$ & $4.60(1 \mathrm{H}$, br. $\mathrm{d}, J=6.3)$ & 36.2 & $4.60(1 \mathrm{H}$, br. $\mathrm{d}, J=6.3)$ & 35.7 \\
\hline \multirow[t]{2}{*}{$8^{\prime \prime}$} & $2.91(1 \mathrm{H}, \mathrm{dd}, J=15.9,1.5)$ & 37.5 & $2.90(1 \mathrm{H}, \mathrm{dd}, J=15.9,1.5)$ & 37.8 \\
\hline & $3.12(1 \mathrm{H}, \mathrm{dd}, J=15.9,7.5)$ & & $3.10(1 \mathrm{H}, \mathrm{dd}, J=15.9,7.4)$ & \\
\hline $9^{\prime \prime}$ & - & 171.0 & - & 170.9 \\
\hline $3^{\prime \prime}-\mathrm{OCH}_{3}$ & - & - & $3.56(3 \mathrm{H}, \mathrm{s})$ & 56.0 \\
\hline 3", $5^{\prime \prime}-\mathrm{OCH}_{3}$ & $3.59(6 \mathrm{H}, \mathrm{s})$ & 56.4 & - & - \\
\hline
\end{tabular}

Figure 3. Main HMBC correlations of compounds 1, 3-6.

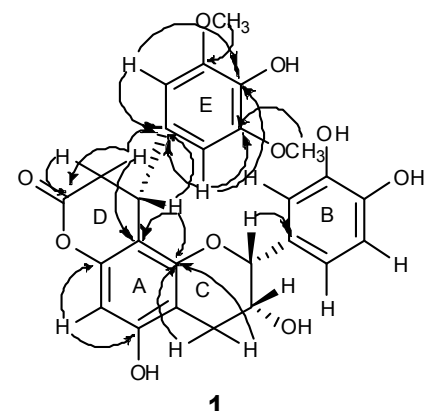

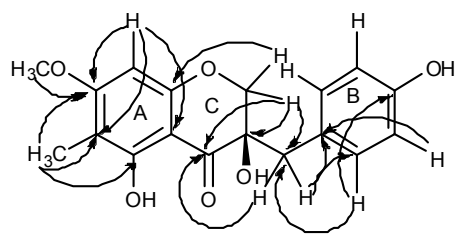

3

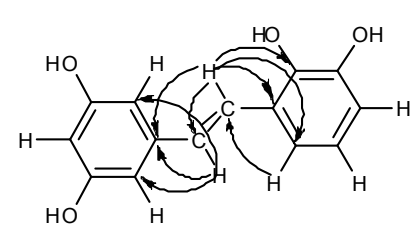

4

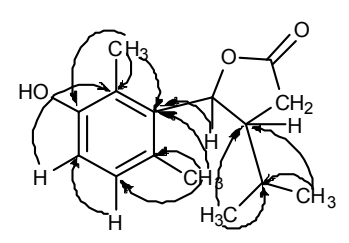

5

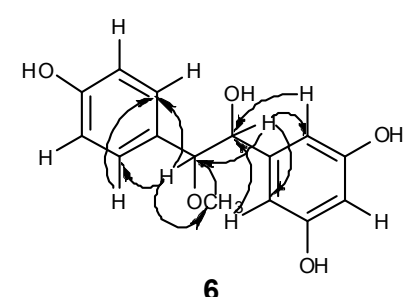

6 
Compound 2 (Figure 1) was isolated as a pale yellow solid. The molecular formula of compound $\mathbf{2}$, $\mathrm{C}_{25} \mathrm{H}_{22} \mathrm{O}_{9}$, was concluded from its HRESIMS, which showed quasi-molecular ion peaks at $\mathrm{m} / \mathrm{z}$ $465.1189[\mathrm{M}-\mathrm{H}]^{-}$(calcd. for $\mathrm{C}_{25} \mathrm{H}_{21} \mathrm{O}_{9}$ 465.1186) and $467.1327[\mathrm{M}+\mathrm{H}]^{+}$(calcd. for $\mathrm{C}_{25} \mathrm{H}_{23} \mathrm{O}_{9}$ 467.1342) in the negative and positive modes, respectively. Its IR spectrum showed absorptions due to hydroxyl $\left(3,453 \mathrm{~cm}^{-1}\right)$ and carbonyl $\left(1,745 \mathrm{~cm}^{-1}\right)$ groups. UV absorptions at 202, 230 and $280 \mathrm{~nm}$ were observed. Detailed ${ }^{1} \mathrm{H},{ }^{13} \mathrm{C}$, and $\mathrm{HMBC}$ spectra suggested 2 to be a phenylpropanoid-substituted epicatechin quite similar to compound 1, but with differences in the substitution pattern of the E-ring. The ${ }^{1} \mathrm{H}-\mathrm{NMR}$ spectrum (Table 1) showed proton signals at $\delta 6.776(1 \mathrm{H}, \mathrm{d}, J=2.0 \mathrm{~Hz}), \delta 6.62(1 \mathrm{H}, \mathrm{d}$, $J=8.2 \mathrm{~Hz})$ and $\delta 6.50(1 \mathrm{H}, \mathrm{dd}, J=8.2,2.0 \mathrm{~Hz})$, revealing the presence of a 1,3,4-trisubstituted aromatic ring. A methoxy group at $\delta 3.56(3 \mathrm{H}, \mathrm{s})$ was observed. The HMBC spectrum showed correlation from the methoxy protons at $\delta 3.56$ to $\delta 148.8$ (C-3"), indicating that the methoxy group was attached to C-3" in the E-ring. To define the absolute configuration of 2 at C-7", a circular dichroism investigation was undertaken. The CD spectrum showed a negative Cotton effects at 234 and $284 \mathrm{~nm}$ and a positive Cotton effect at $256 \mathrm{~nm}$. Thus, C-7" also possessed the $R$ configuration [13]. Accordingly, compound 2 was determined as epicatechin-(7,8-bc)-4 $\alpha$-(3-methoxy-4-hydroxy-phenyl)dihydro-2(3H)-pyranone, and trivially named smiglabrone $\mathrm{B}$.

Compound 3 (Figure 1) was obtained as a pale yellow solid. Its molecular formula was determined as $\mathrm{C}_{18} \mathrm{H}_{18} \mathrm{O}_{6}$ from the negative-ion HRESIMS with a quasi-molecular ion peak at $\mathrm{m} / z 329.1033$ $[\mathrm{M}-\mathrm{H}]^{-}$(calcd. for $\mathrm{C}_{18} \mathrm{H}_{17} \mathrm{O}_{6} 329.1025$ ). The IR spectrum of 3 showed characteristic absorption bands for hydroxyl $\left(3,450 \mathrm{~cm}^{-1}\right)$ and carbonyl $\left(1,633 \mathrm{~cm}^{-1}\right)$ groups. UV absorptions at 216 and $294 \mathrm{~nm}$ were observed. The ${ }^{1} \mathrm{H}-\mathrm{NMR}$ spectrum (Table 2) revealed a set of characteristic signals at $\delta 4.06(1 \mathrm{H}, \mathrm{d}$, $J=11.0 \mathrm{~Hz})$ and $3.96(1 \mathrm{H}, \mathrm{d}, J=11.0 \mathrm{~Hz})$ for one methylene linked to an oxygen atom, at $\delta 2.90(1 \mathrm{H}$, $\mathrm{d}, J=14.5 \mathrm{~Hz})$ and $2.86(1 \mathrm{H}, \mathrm{d}, J=14.5 \mathrm{~Hz})$ for one benzylic methylene, indicating that 3 possessed a homoisoflavanone skeleton. A trisubstitution of the A-ring was deduced from the occurence of a one aromatic proton singlet at $\delta 6.14$, suggesting a substituent either at $\mathrm{C}-6$ or at C-8. Four aromatic protons at $\delta 7.05(2 \mathrm{H}, \mathrm{d}, J=8.5 \mathrm{~Hz})$ and $6.70(2 \mathrm{H}, \mathrm{d}, J=8.5 \mathrm{~Hz})$ revealed a 1,4-disubstituted B-ring. In addition, an aromatic methoxyl group at $\delta 3.86(3 \mathrm{H}, \mathrm{s})$ and a methyl group at $\delta 1.95(3 \mathrm{H}, \mathrm{s})$ were also observed in the ${ }^{1} \mathrm{H}-\mathrm{NMR}$ spectrum. The ${ }^{13} \mathrm{C}$-NMR spectrum (Table 2) exhibited, in total, eighteen carbon resonances, including one aromatic carbon linked to a carbonyl at $\delta 101.8$, one alkyl-substituted aromatic carbon at $\delta 126.8$, one flavanone carbonyl carbon at $\delta 200.6$, one methylene carbon having an oxygen function at $\delta 72.9$, one benzylic methylene carbon at $\delta 40.8$, one methoxyl carbon at $\delta 56.5$, one methyl carbon at $\delta 7.0$, and one quaternary carbon having an oxygen function at $\delta$ 73.6. The HMBC correlation of the methoxyl protons at $\delta 3.86$ with $\mathrm{C}-7$ at $\delta 167.5$ indicated that the linkage position of the methoxyl group was at C-7. The position for the methyl group attaching at C-6 was determined by correlation from methyl protons at $\delta 1.95$ to C-6 $(\delta 106.7)$. The long-range correlation from H-2 to C-9 $(\delta$ 162.7), C-4 ( $\delta$ 200.6) and C-11 ( $\delta$ 40.8), from H-11 to C-4 $(\delta$ 200.6) and C-2' ( $\delta$ 132.8) further confirmed the speculation of the structure of compound 3 (Figure 3 ). The planar structure of compound 3 was identified as 3,5-dihydroxy-7-methoxy-6-methyl-3-(4hydroxybenzyl)chroman-4-one [14]. The absolute configuration of C-3 was assessed by optical its rotation $\left([\alpha]_{\mathrm{D}}^{20}+178.72\right)$, indicating the $R$ configuration at C-3 [15]. Consequently, the structure of compound 3 was identified as (3R)-3,5-dihydroxy-7-methoxy-6-methyl-3-(4-hydroxybenzyl)chroman4-one, and trivially named smilachromanone. 
Table 2. ${ }^{1} \mathrm{H}-\mathrm{NMR}(500 \mathrm{MHz})$ and ${ }^{13} \mathrm{C}-\mathrm{NMR}(125 \mathrm{MHz})$ spectra data of compound 3 (in $\mathrm{CD}_{3} \mathrm{OD}, J$ in $\mathrm{Hz}, \delta$ in ppm).

\begin{tabular}{ccc}
\hline Position & $\boldsymbol{\delta}_{\mathbf{H}}(\boldsymbol{J} \mathbf{~ i n ~ H z})$ & $\boldsymbol{\delta}_{\mathbf{C}}$ \\
\hline 2 & $4.06(1 \mathrm{H}, \mathrm{d}, J=11.0)$ & 72.9 \\
& $3.96(1 \mathrm{H}, \mathrm{d}, J=11.0)$ & - \\
4 & - & 73.6 \\
5 & - & 200.6 \\
6 & - & 161.6 \\
7 & - & 106.7 \\
8 & - & 167.5 \\
9 & $-14(1 \mathrm{H}, \mathrm{s})$ & 91.8 \\
10 & - & 162.7 \\
11 & $2.90(1 \mathrm{H}, \mathrm{d}, J=14.5)$ & 101.8 \\
& $2.86(1 \mathrm{H}, \mathrm{d}, J=14.5)$ & 40.8 \\
$1^{\prime}$ & - & - \\
$2^{\prime}, 6^{\prime}$ & $7.05(2 \mathrm{H}, \mathrm{d}, J=8.5)$ & 126.8 \\
$3^{\prime}, 5^{\prime}$ & $6.70(2 \mathrm{H}, \mathrm{d}, J=8.5)$ & 132.8 \\
$4^{\prime}$ & - & 115.9 \\
$7-\mathrm{OCH}_{3}$ & $3.86(3 \mathrm{H}, \mathrm{s})$ & 56.5 \\
$6-\mathrm{CH}_{3}$ & $1.95(3 \mathrm{H}, \mathrm{s})$ & 7.0 \\
\hline
\end{tabular}

Compound 4 (Figure 1) was obtained as a brown-yellow powder. Its molecular formula was determined as $\mathrm{C}_{14} \mathrm{H}_{12} \mathrm{O}_{4}$ by negative-ion HRESIMS with quasi-molecular ion peaks at $\mathrm{m} / z 243.0659$ [M-H] $]^{-}$(calcd. for $\mathrm{C}_{14} \mathrm{H}_{11} \mathrm{O}_{4}$ 243.0657). The IR spectrum of 4 showed a characteristic hydroxyl absorption band $\left(3,449 \mathrm{~cm}^{-1}\right)$. UV absorptions at 220 and $306 \mathrm{~nm}$ were observed. The ${ }^{1} \mathrm{H}-\mathrm{NMR}$ spectrum (Table 3) exhibited proton signals at $\delta 6.48(2 \mathrm{H}, \mathrm{d}, J=1.8 \mathrm{~Hz})$ and $6.17(1 \mathrm{H}, \mathrm{t}, J=1.8 \mathrm{~Hz})$, suggesting the presence of a 1,3,5-trisubstituted aromatic ring in the molecule. The signals at $\delta 7.37$ $(1 \mathrm{H}, \mathrm{d}, J=16.8 \mathrm{~Hz})$ and $6.96(1 \mathrm{H}, \mathrm{d}, J=16.8 \mathrm{~Hz})$ were attributed to a set of trans-olefinic protons. The remaining protons at $\delta 6.69(1 \mathrm{H}, \mathrm{dd}, J=1.8,7.8 \mathrm{~Hz}), 6.66(1 \mathrm{H}, \mathrm{t}, J=7.8 \mathrm{~Hz})$ and $7.02(1 \mathrm{H}, \mathrm{dd}$, $J=1.8,7.8 \mathrm{~Hz}$ ) indicated the existence of a 1,2,3-trisubstituted aromatic ring. The ${ }^{13} \mathrm{C}-\mathrm{NMR}$ spectrum (Table 3) exhibited, in total, twelve carbon resonances including two olefinic carbons and ten aromatic carbons. The HMBC spectrum showed correlations from $\mathrm{H}-7$ to $\mathrm{C}-1^{\prime}(\delta 141.6)$ and $\mathrm{C}-2^{\prime}, 6^{\prime}(\delta 105.9)$, indicating that C-7, C-2' and C-6' were linked through C-1'; the correlations from H-8 to C-1 ( $\delta 126.0)$, C-2 $(\delta$ 144.6) and C-6 ( $\delta$ 118.3), suggesting that C-8, C-2 and C-6 were linked through C-1 (Figure 3). Accordingly, compound 4 was elucidated as (E)-3-(3,5-dihydroxystyryl)benzene-1,2-diol, and trivially named smiglastilbene. 
Table 3. ${ }^{1} \mathrm{H}-\mathrm{NMR}(600 \mathrm{MHz})$ and ${ }^{13} \mathrm{C}-\mathrm{NMR}(150 \mathrm{MHz})$ spectra data of compound 4 (in $\mathrm{CD}_{3} \mathrm{OD}, J$ in $\mathrm{Hz}, \delta$ in ppm).

\begin{tabular}{ccc}
\hline Position & $\boldsymbol{\delta}_{\mathbf{H}}(\boldsymbol{J}$ in $\mathbf{H z})$ & $\boldsymbol{\delta}_{\mathbf{C}}$ \\
\hline 1 & - & 126.0 \\
2 & - & 144.6 \\
3 & - & 146.5 \\
4 & $6.69(1 \mathrm{H}, \mathrm{dd}, J=7.8,1.8)$ & 114.9 \\
5 & $6.66(1 \mathrm{H}, \mathrm{t}, J=7.8)$ & 120.5 \\
6 & $7.02(1 \mathrm{H}, \mathrm{dd}, J=7.8,1.8)$ & 118.3 \\
7 & $6.96(1 \mathrm{H}, \mathrm{d}, J=16.8)$ & 129.5 \\
8 & $7.37(1 \mathrm{H}, \mathrm{d}, J=16.8)$ & 124.7 \\
$1^{\prime}$ & - & 141.6 \\
$2^{\prime}, 6^{\prime}$ & $6.48(2 \mathrm{H}, \mathrm{d}, J=1.8)$ & 105.9 \\
$3^{\prime}, 5^{\prime}$ & - & 159.7 \\
$4^{\prime}$ & $6.17(1 \mathrm{H}, \mathrm{t}, J=1.8)$ & 102.8 \\
\hline
\end{tabular}

Compound 5 (Figure 1) was obtained as a white powder. Its molecular formula was determined as $\mathrm{C}_{15} \mathrm{H}_{20} \mathrm{O}_{3}$ by HREIMS with a molecular ion peak at $\mathrm{m} / z$ 248.1415 [M] ${ }^{+}$(calcd. for $\mathrm{C}_{15} \mathrm{H}_{20} \mathrm{O}_{3}$ 248.1412). The IR spectrum of 5 showed characteristic absorption bands for hydroxyl $\left(3,357 \mathrm{~cm}^{-1}\right)$ and carbonyl $\left(1,747 \mathrm{~cm}^{-1}\right)$ groups. UV absorptions at 201 and $289 \mathrm{~nm}$ were observed. The ${ }^{1} \mathrm{H}-\mathrm{NMR}$ spectrum (Table 4) displayed four methyl groups at $\delta 0.76(3 \mathrm{H}, \mathrm{d}, J=6.6 \mathrm{~Hz}), 0.98(3 \mathrm{H}, \mathrm{d}, J=6.6$ $\mathrm{Hz}), 2.30(3 \mathrm{H}, \mathrm{s}), 2.22(3 \mathrm{H}, \mathrm{s})$, a proton signal at $\delta 5.72(1 \mathrm{H}, \mathrm{d}, J=9.0 \mathrm{~Hz})$ attached to the oxygenated carbon, and two methenyl proton signals at $\delta 2.75(1 \mathrm{H}, \mathrm{m})$ and $1.76(1 \mathrm{H}, \mathrm{m})$. In addition, a pair of vicinal coupled aromatic proton signals at $\delta 6.85(1 \mathrm{H}, \mathrm{d}, J=8.4 \mathrm{~Hz}), 6.69(1 \mathrm{H}, \mathrm{d}, J=8.4 \mathrm{~Hz})$ indicated the presence of one 1,2,3,4-tetrasubstituted phenyl ring. The ${ }^{13} \mathrm{C}$-NMR spectrum (Table 4) exhibited one quaternary carbon signal attached to the O-atom at $\delta 179.6$; four other quaternary carbons in the benzene ring at $\delta 156.2,136.3,128.9$ and 125.2. Among these signals, the lower field carbon signal at $\delta 156.2$ indicated that this $\mathrm{C}$-atom was connected to the $\mathrm{O}$-atom. The ${ }^{13} \mathrm{C}$-NMR spectrum also gave two tertiary carbons in the benzene ring at $\delta 130.7$ and 116.2, one methylene carbon at $\delta 33.8$, three methenyl carbons at $\delta 49.5,85.1$ and 31.3, four methyl carbons at $\delta 21.9,19.9,20.8$ and 13.0. From the above information it was possible to deduce the presence of dihydrofuran in the molecule. The HMBC spectrum showed correlations from H-15 to C-5 ( $\delta$ 136.3), C-9 $(\delta$ 156.2) and C-10 $(\delta$ 125.2), from H-14 to C-5 ( $\delta$ 136.3), C-6 ( $\delta$ 128.9) and C-7 ( $\delta$ 130.7), thus indicating that two methyl groups are placed at $\mathrm{C}-10$ and $\mathrm{C}-6$, respectively. The HMBC correlations from $\mathrm{H}-12$ and $\mathrm{H}-13$ to $\mathrm{C}-11(\delta 31.3)$ and $\mathrm{C}-3(\delta 49.5)$ indicated that the presence of an isopropyl at $\mathrm{C}-3$; the correlation from $\delta 5.72(1 \mathrm{H}, \mathrm{d}$, $J=9.0 \mathrm{~Hz}, \mathrm{H}-4)$ to $\mathrm{C}-5$ ( $\delta$ 136.3) suggested that the dihydrofuran was connected to C-5 in the benzene ring (Figure 3). The relative configuration of H-3 and H-4 was determined as trans by the $9.0 \mathrm{~Hz}$ coupling constant between H-3 and H-4. Irradiation of H-4 caused NOE enhancements of H-11, H-12 and H-13 in the 1D NOE spectra and indicated that isopropyl was positioned in the same plane with $\mathrm{H}-4$. Thus, the NOE result further confirmed the trans conformation of $\mathrm{H}-4$ and $\mathrm{H}-3$. Consequently, compound 5 was elucidated as 5-(3-hydroxy-2,6-dimethylphenyl)-4-isopropyldihydrofuran-2(3H)-one, trivially named smiglactone. 
Table 4. ${ }^{1} \mathrm{H}-\mathrm{NMR}(600 \mathrm{MHz})$ and ${ }^{13} \mathrm{C}-\mathrm{NMR}(150 \mathrm{MHz})$ spectra data of compound $\mathbf{5}$ (in $\mathrm{CD}_{3} \mathrm{OD}, J$ in $\mathrm{Hz}, \delta$ in ppm).

\begin{tabular}{ccc}
\hline Position & $\boldsymbol{\delta}_{\mathbf{H}}(\boldsymbol{J}$ in $\mathbf{~ H z})$ & $\boldsymbol{\delta}_{\mathbf{C}}$ \\
\hline 1 & - & 179.6 \\
2 & $2.65(2 \mathrm{H}, \mathrm{m})$ & 33.8 \\
3 & $2.75(1 \mathrm{H}, \mathrm{m})$ & 49.5 \\
4 & $5.72(1 \mathrm{H}, \mathrm{d}, J=9.0)$ & 85.1 \\
5 & - & 136.3 \\
6 & - & 128.9 \\
7 & $6.85(1 \mathrm{H}, \mathrm{d}, J=8.4)$ & 130.7 \\
8 & $6.69(1 \mathrm{H}, \mathrm{d}, J=8.4)$ & 116.2 \\
9 & - & 156.2 \\
10 & - & 125.2 \\
11 & $1.76(1 \mathrm{H}, \mathrm{m})$ & 31.3 \\
12 & $0.76(3 \mathrm{H}, \mathrm{d}, J=6.6)$ & 21.9 \\
13 & $0.98(3 \mathrm{H}, \mathrm{d}, J=6.6)$ & 19.9 \\
14 & $2.30(3 \mathrm{H}, \mathrm{s})$ & 20.8 \\
15 & $2.22(3 \mathrm{H}, \mathrm{s})$ & 13.0 \\
\hline
\end{tabular}

Compound 6 (Figure 1) was obtained as a pale yellow solid. Its molecular formula was determined as $\mathrm{C}_{15} \mathrm{H}_{16} \mathrm{O}_{5}$ by negative-ion HRESIMS with quasi-molecular ion peaks at $m / z 311.06917[\mathrm{M}+\mathrm{Cl}]^{-}$, $338.08813\left[\mathrm{M}+\mathrm{NO}_{3}\right]^{-}$and $587.16893[2 \mathrm{M}+\mathrm{Cl}]^{-}$(calcd. for $\mathrm{C}_{15} \mathrm{H}_{16} \mathrm{O}_{5} \mathrm{Cl} 311.06921, \mathrm{C}_{15} \mathrm{H}_{16} \mathrm{O}_{5} \mathrm{NO}_{3}$ 338.08835 and $\mathrm{C}_{30} \mathrm{H}_{32} \mathrm{O}_{10} \mathrm{Cl} 587.16829$, respectively). The IR spectrum of 6 showed a characteristic hydroxyl absorption band $\left(3,336 \mathrm{~cm}^{-1}\right)$. UV absorptions at 206, 225 and $278 \mathrm{~nm}$ was observed. The ${ }^{1} \mathrm{H}-\mathrm{NMR}$ spectrum (Table 5) showed proton signals at $\delta 7.30(2 \mathrm{H}, \mathrm{d}, J=8.4 \mathrm{~Hz})$ and $7.06(2 \mathrm{H}, \mathrm{d}$, $J=8.4 \mathrm{~Hz})$, revealing the presence of a 1,4-disubstituted aromatic ring, and the signals at $\delta 6.88(1 \mathrm{H}, \mathrm{t}$, $J=2.4 \mathrm{~Hz})$ and $6.97(2 \mathrm{H}, \mathrm{d}, J=2.4 \mathrm{~Hz})$ indicating the presence of a 1,3,5-trisubstituted aromatic ring. The ${ }^{1} \mathrm{H}-\mathrm{NMR}$ spectrum of 6 also indicated the presence of four hydroxyl groups at $\delta 11.24(2 \mathrm{H}, \mathrm{br} . \mathrm{s})$, $11.38\left(1 \mathrm{H}\right.$, br. s) and $3.59\left(1 \mathrm{H}\right.$, br. s), and one methoxy group at $\delta 3.28(3 \mathrm{H}, \mathrm{s})$. The ${ }^{13} \mathrm{C}-\mathrm{NMR}$ spectrum (Table 5) exhibited, in total, eleven carbon resonances involving eight aromatic carbons, a methoxy carbon, and two oxygenated carbons. In the HMBC spectrum, the correlations from methoxy proton at $\delta 3.28(3 \mathrm{H}, \mathrm{s})$ to $\mathrm{C}-8(\delta 89.5)$, and from $\mathrm{H}-8$ to methoxy carbon at $\delta 56.8$ suggested that the methoxy group was connected with $\mathrm{C}-8$. The correlations from $\mathrm{H}-8$ to $\mathrm{C}-10,14(\delta 129.9), \mathrm{H}-14$ to $\mathrm{C}-10(\delta$ 129.9) indicated that $\mathrm{C}-8, \mathrm{C}-10$ and $\mathrm{C}-14$ were linked through $\mathrm{C}-9$; the correlations from $\mathrm{H}-7$ to $\mathrm{C}-4,6(\delta$ 107.1), H-6 to C-7 ( $\delta$ 78.7) and H-4 to C-7 ( $\delta$ 78.7) suggested that C-7, C-4 and C-6 were linked through C-5 (Figure 3). The large coupling constant between $\mathrm{H}-7$ and $\mathrm{H}-8(J=7.8 \mathrm{~Hz})$ suggested a threo conformation of C-7/C-8 [16,17]. Thus, the structure of compound 6 was determined as threo-5-[1-hydroxy-2-(4-hydroxyphenyl)-2-methoxyethyl] benzene-1,3-diol, trivially named smiglabrol. 
Table 5. ${ }^{1} \mathrm{H}-\mathrm{NMR}(600 \mathrm{MHz})$ and ${ }^{13} \mathrm{C}-\mathrm{NMR}(150 \mathrm{MHz})$ spectra data of compound $\mathbf{6}$ (in $\mathrm{C}_{5} \mathrm{D}_{5} \mathrm{~N}, J$ in $\mathrm{Hz}, \delta$ in ppm).

\begin{tabular}{ccc}
\hline Position & $\boldsymbol{\delta}_{\mathbf{H}}(\boldsymbol{J}$ in $\mathbf{H z})$ & $\boldsymbol{\delta}_{\mathbf{C}}$ \\
\hline 1,3 & - & 159.7 \\
2 & $6.88(1 \mathrm{H}, \mathrm{t}, J=2.4)$ & 102.9 \\
4,6 & $6.97(2 \mathrm{H}, \mathrm{d}, J=2.4)$ & 107.1 \\
5 & - & 145.4 \\
7 & $5.13(1 \mathrm{H}, \mathrm{d}, J=7.8)$ & 78.7 \\
8 & $4.56(1 \mathrm{H}, \mathrm{d}, J=7.8)$ & 89.5 \\
9 & - & 130.0 \\
10,14 & $7.30(2 \mathrm{H}, \mathrm{d}, J=8.4)$ & 129.9 \\
11,13 & $7.06(2 \mathrm{H}, \mathrm{d}, J=8.4)$ & 115.7 \\
12 & - & 158.4 \\
$1,3-\mathrm{OH}$ & $11.24(2 \mathrm{H}$, br. s $)$ & - \\
$7-\mathrm{OH}$ & $3.59(1 \mathrm{H}$, br. s $)$ & - \\
$8-\mathrm{OCH}$ & $3.28(3 \mathrm{H}, \mathrm{s})$ & 56.7 \\
$12-\mathrm{OH}$ & $11.38(1 \mathrm{H}$, br. s $)$ & - \\
\hline
\end{tabular}

\subsection{Structural Elucidation of the Known Isolates}

Compound 43 (Figure 2) was isolated as a pale yellow powder. Its molecular formula was determined as $\mathrm{C}_{21} \mathrm{H}_{20} \mathrm{O}_{7}$ from the negative-ion HRESIMS with a quasi-molecular ion peak at $\mathrm{m} / \mathrm{z}$ $383.1133[\mathrm{M}-\mathrm{H}]^{-}$(calcd. for $\mathrm{C}_{21} \mathrm{H}_{19} \mathrm{O}_{7}$ 383.1131) and the positive negative-ion HRESIMS at $\mathrm{m} / \mathrm{z}$ $407.1103[\mathrm{M}+\mathrm{Na}]^{+}$(calcd. for $\mathrm{C}_{21} \mathrm{H}_{20} \mathrm{O}_{7} \mathrm{Na}$ 407.1107). The IR spectrum of 43 showed characteristic absorption bands for hydroxyl $\left(3,448 \mathrm{~cm}^{-1}\right)$ and carbonyl $\left(1,686 \mathrm{~cm}^{-1}\right)$ groups. UV absorptions at 210 , 228 and $310 \mathrm{~nm}$ were observed. The ${ }^{1} \mathrm{H}-\mathrm{NMR}$ spectrum exhibited signals of two trans-double bonds at $\delta 7.57(1 \mathrm{H}, \mathrm{d}, J=16.2 \mathrm{~Hz}), 6.39(1 \mathrm{H}, \mathrm{d}, J=16.2 \mathrm{~Hz}), 7.540(1 \mathrm{H}, \mathrm{d}, J=15.6 \mathrm{~Hz})$ and $6.38(1 \mathrm{H}, \mathrm{d}$, $J=15.6 \mathrm{~Hz})$. Eight aromatic protons at $\delta 7.541(2 \mathrm{H}, \mathrm{d}, J=8.4 \mathrm{~Hz}), 6.77(2 \mathrm{H}, \mathrm{d}, J=8.4 \mathrm{~Hz}), 7.53(2 \mathrm{H}$, $\mathrm{d}, J=8.4 \mathrm{~Hz})$ and $6.76(2 \mathrm{H}, \mathrm{d}, J=8.4 \mathrm{~Hz})$, revealing the presence of two 1,4-disubstituted aromatic rings. Additionally, an acylated methine proton at $\delta 5.11(1 \mathrm{H}, \mathrm{m})$, acylated methylene protons at $\delta 4.40$ $(1 \mathrm{H}, \mathrm{dd}, J=11.4,3.0 \mathrm{~Hz})$ and $4.25(1 \mathrm{H}, \mathrm{dd}, J=12.0,6.6 \mathrm{~Hz})$, and hydroxymethyl protons at $3.60(2 \mathrm{H}$, t) suggested the presence of a 1,2-diacylglycerol moiety. The ${ }^{13} \mathrm{C}-\mathrm{NMR}$ spectrum showed two ester carbonyl carbon signals at $\delta 166.41$ and 166.19 , four olefinic carbons at $\delta 114.03,145.21,113.68$ and 145.16, one oxymethine carbon at $\delta 72.13$, and one oxymethylene carbon at $\delta 62.54$. The HMBC correlation of H-1, H-6 with $\delta 166.19$ (C-4), H-3' with $\delta 166.41$ (C-1') further confirmed the presence of two non-equivalent $p$-coumarate moieties. The HMBC spectrum showed correlations from $\mathrm{H}-1, \mathrm{H}-3$ to $\delta 72.13$ (C-2), H-1 to $\delta 59.67$ (C-3), indicating that the hydroxymethyl and acylated methylene were linked through $\mathrm{C}-2$. Thus, the planar structure of $\mathbf{4 3}$ was determined as 1,2-O-di-trans- $p$ coumaroylglycerol, that was reported as being isolated from stromata of Epichloe typhina on Phleum pretense [18]. To determine the absolute configuration of $\mathbf{4 3}$, the exciton-coupled circular dichroism (ECCD) technique was applied [19,20]. The CD of $\mathbf{4 3}$ (Figure 4) exhibited a positive split between the two chromophores of the $p$-coumarate coupled with $\pi \rightarrow \pi^{*}$ transition (287 nm, $\Delta \varepsilon-11.12 ; 326 \mathrm{~nm}, \Delta \varepsilon$ +14.09), indicating that the transition dipole moments of the two chromophores were oriented in a 
clockwise manner. This positive $\mathrm{CD}$ shows that the electric transition dipole of the $p$-coumarate chromophores constitute positive chirality. Thus the absolute configuration of the chiral center in $\mathbf{4 3}$ was deduced as $2 S$. Accordingly, compound 43 was elucidated as $\left(2 E, 2^{\prime} E\right)-[(S)-3$-hydroxypropane1,2-diyl] bis[3-(4-hydroxyphenyl)acrylate], and the compound was trivially named smiglycerol.

Figure 4. CD and UV spectra of compound 43.

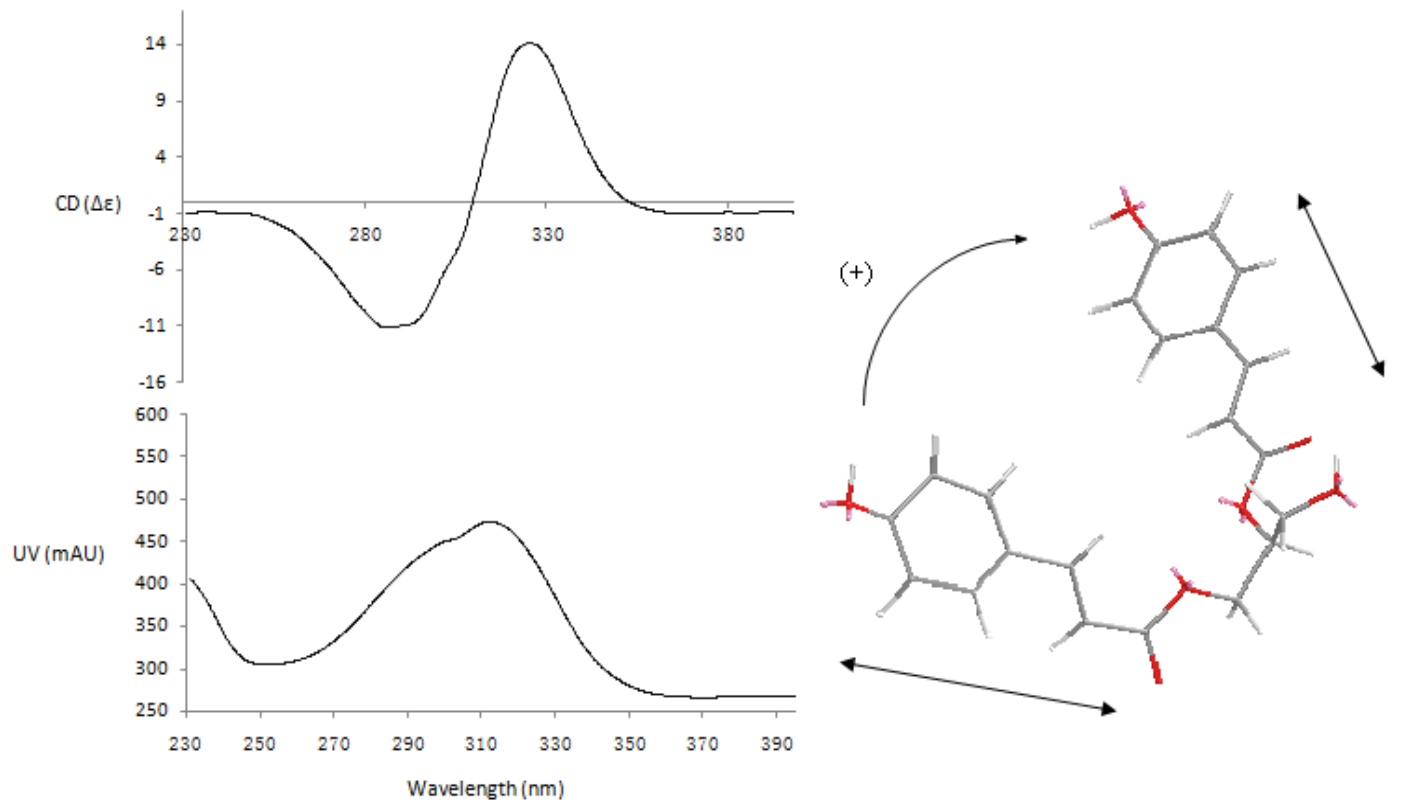

Based on their 1D and 2D NMR, CD and MS spectroscopic data and comparison of the data with those reported in the literature, fifty-seven known compounds were identified. These included thirteen flavanones: taxifolin (7) [7], naringenin (8), dihydrokaempferol (9) [21], sakuranetin (10) [22], isoastilbin (11) [23], astilbin (12) [23], neoastilbin (13) [23], neoisoastilbin (14) [23], engeletin (15) [21], arthromerin B (16) [23,24], sinensin (17) [23,25], $(2 R, 3 R)$-taxifolin 3'- $O$ - $\beta$-D-glucopyranoside (18), (2S,3S)-glucodistylin (19) [26], four flavanes: (-)-epicatechin (20) [13], (+)-catechin (21) [12], cinchonain Ib (22) [13], cinchonain Ia (23) [13], four flavonoids: apigenin (24), quercetin (25), luteolin (26), myricetin (27), one chalcone, kukulkanin B (28) [27], two aurones: 4,4',6-trihydroxyaurone (29) [28], aureusidin (30) [29], six lignans: (-)-secoisolariciresinol (31) [30], 4-ketopinoresinol (32) [31], 1,4-bis(4-hydroxy-3,5-dimethoxyphenyl)-2,3-bis(hydroxymethyl)-1,4-butanediol (named smiglabranol by us for being utilized conveniently in future) (33) [32], (+)-lyoniresinol (34) [33], kompasinol A (35) [34], aiphanol (36) [35], three stilbenes: trans-resveratrol (37) [36], trans-piceid (38) [36], piceatannol (39) [36], six phenylpropanoids: trans-caffeic acid (40), 5-O-caffeoylshikimic acid (41) [21], 3-O-p-coumaroylshikimic acid (42) [37], (2S)-1,2-O-di-trans-p-coumaroylglycerol (named smiglycerol) (43) [18], juncusyl ester B (44) [38], 1-O-p-coumaroylglycerol (45) [39], nine phenolics: vanillin (46), $p$-hydroxy-benzaldehyde (47), acetovanillone (48), (+)-scytalone (49) [40], glucosyringic acid (50), protocatechuic acid (51), 3-methoxygallic acid (52), vanillic acid 1-O- $\beta$-D-glucopyranosyl ester (53), hydroxytyrosol (54), one triterpene, acetyl-11-keto- $\beta$-boswellic acid (55), three steroids: stigmasterol (56), $\beta$-sitosterol (57), daucosterol (58), and five other compounds: smilagenin (59), 5-hydroxymaltol (60), 5-hydroxyuridine (61), 2-methylbutanedioic acid-4-ethyl ester (62), isoselachoceric acid (63) (see Figure 2). Isolation of twenty-seven compounds (10, 17, 26-36, 42, 43, 
45, 46, 48-50, 52-55, 60-62) from the genus Smilax is reported here for the first time and fourteen compounds $(9, \mathbf{1 5}, \mathbf{1 6}, \mathbf{1 9}, \mathbf{2 1}-\mathbf{2 4}, \mathbf{3 9}, \mathbf{4 0}, \mathbf{4 4}, \mathbf{4 7}, \mathbf{5 1}, \mathbf{6 3})$ were obtained from the rhizomes of $S$. glabra for the first time.

During our investigations, four phenylpropanoid-substituted epicatechins (compounds 1, 2, 22, 23), which were a class of flavan-3-ols substituted at the $A$ ring with a $\mathrm{C}_{6}-\mathrm{C}_{3}$ unit, were obtained. To our knowledge, these have never been previously reported in $S$. glabra. Pharmacological studies revealed that compounds 22 and $\mathbf{2 3}$ possessed antioxidant [10], antifungal and antiviral [11] activities. This is the first report of the presence in Smilax of chalcone 28, which was previously isolated from Mimosa tenuefolia [27]. Compounds with this skeleton were found to have antioxidant [41] and antitumor [42] activities. The two aurones, namely compounds 29 and 30, were found to possess antiviral [28] and antioxidant [29] activities, respectively. Their isolation from the genus Smilax is reported here for the first time. Compound 36 represents a stilbenolignan skeleton in which a stilbene moiety is linked with a phenylpropane unit through a dioxane bridge. It was previously reported from Aiphanes aculeate and exhibited significant inhibitory activities against cyclooxygenases-1 and -2 [35]. Compound 35 is also a stilbenolignan, which was isolated from Koompassia malaccensis [34] and Syagrus romanzoffiana and had anti- $\alpha$-glucosidase activity [43]. This is first report of the presence of compounds with this type of skeleton in Smilax plants.

On the basis of previous phytochemical studies and our investigations, flavonoids are the main constituents in the rhizomes of $S$. glabra, and especially flavanones were relatively more abundant than other kinds of flavonoids. It was reported that the contents of the five flavonoids were in the range of 0.0290-1.06, 0.0128-0.0543, 1.53-11.3, 0.449-13.7 and 0.552-4.837 mg/g crude drugs for taxifolin, neoastilbin, astilbin, neoisoastilbin and isoastilbin, respectively [8]. In addition, quantitative analysis showed that the content of engeletin was in the range of $0.14-3.1 \mathrm{mg} / \mathrm{g}$ crude drug [44]. Previous phytochemical investigations showed that fourteen flavonoids were isolated the rhizomes of $S$. glabra, which included ten flavanones: taxifolin, astilbin, neoastilbin, isoastilbin, neoisoastilbin, $(2 R, 3 R)$ taxifolin-3'-O- $\beta$-D-glucopyranoside, isoengelitin, naringenin, engeletin, smitilbin [45-47], two flavonoids: quercetin, quercetin $4^{\prime}-O-\beta$-D-glucoside [48], one isoflavone, $7,6^{\prime}$-dihydroxy-3'-methoxyisoflavone [46], and one flavane, (-)-epicatechin [49].

\subsection{Antimicrobial Activity}

The MIC obtained in the antimicrobial assessment of $S$. glabra extracts demonstrated considerable activity in the ethanolic extract, ethyl acetate fraction and $n$-butanol fraction against $S$. aureus ATCC6538 $(50 \mu \mathrm{g} / \mathrm{mL})$. The ethyl acetate fraction and water fraction showed activity against $C$. albicans SC5314 and S. aureus ATCC6538 with MIC values of $200 \mu \mathrm{g} / \mathrm{mL}$. This is the first report on the antifungal properties of S. glabra.

Thirty compounds were tested for their antimicrobial activity (Table 6). The results demonstrated that seventeen of these compounds were found to have antibacterial activity against Gram-positive bacteria and ten compounds displayed activity against the tested fungus, while eight compounds were found to be antibacterial against Gram-negative bacteria. As for the four flavan-3-ols (Figure S1 and Table S1), 1, 20 and 22 demonstrated antimicrobial properties, whereas $\mathbf{2 1}$ was inactive in the concentration range tested. Compound $\mathbf{1}$ exhibited activity against all tested microorganisms, which 
was stronger against $C$. albicans SC5314 with a MIC value of $0.146 \mathrm{mM}$ and weaker against the Gram-positive and Gram-negative bacteria where the MIC values were in the range of 0.302-0.604 $\mathrm{mM}$. Compound 22 showed activity against methicillin-resistant $S$. aureus and $S$. aureus ATCC6538 with a MIC value of $0.0801 \mathrm{mM}$ and activity against $C$. albicans SC5314 and E. faecalis with MIC valued of $0.160 \mathrm{mM}$. Compound 20 was only found to be active against methicillin-resistant $S$. aureus, S. aureus ATCC6538 and E. faecalis. Compounds 1, 20 and 22 all possessed epicatechin units, while 21 was identified as catechin. The result suggested that the antimicrobial activity was influenced by the stereochemistry at $\mathrm{C} 2$ and $\mathrm{C} 3$.

A similar situation happens with respect to some of the investigated flavanones. Compound 7 was inactive and its flavanonol rhamnoside isomers (compounds 12, 13 and 14) showed antimicrobial activity except for $\mathbf{1 1}$ (Figure S2 and Table S2). Among them, compound 14, with 2S,3R configuration, presented the best activity and showed inhibitory effects toward all of the tested microorganisms. This indicates that the stereochemistry at C2 and C3 of taxifolin largely governs the potency of inhibition, and controls the steric configuration of the rhamnose moiety. Taxifolin (7), astilbin (12), neoastilbin (13) and isoastilbin (11) have been found to display antimicrobial activity against Streptococcus sobrinus with MIC values in the $0.500-0.740 \mathrm{mM}$ range. Among these compounds, neoastilbin showed an especially potent GTase inhibitory activity, which suggested that the antimicrobial activity was related to stereochemistry [7]. To some extent, our results mirror the previous study [7].

Compound 9 and its glycoside (compound 17) demonstrated activity against methicillin-resistant $S$. aureus and $S$. aureus ATCC6538, whereas $\mathbf{1 5}$ and $\mathbf{1 6}$ did not show inhibitory effects toward these microorganisms. This implied that for the $\mathrm{C}$ ring, hydroxylation at position 3 improved the activity of flavanones (Figure S3 and Table S3). Compound $\mathbf{1 0}$ was found to be antibacterial against methicillin-resistant $S$. aureus, $S$. aureus ATCC6538 and E. faecalis with MIC values of 0.524, 0.524 and $1.05 \mathrm{mM}$. The homoisoflavanone 3 showed antibacterial activity against $S$. aureus ATCC6538, with a MIC value of $0.303 \mathrm{mM}$, and weaker activity against $C$. albicans SC5314, methicillin-resistant $S$. aureus and E. faecalis with a uniform MIC of $0.605 \mathrm{mM}$.

All the investigated stibenes (compounds 4, 37-39) displayed antimicrobial activity against the microorganisms tested (Figures S4 and S5, Table S4). Compound 37 showed antibacterial activity against methicillin-resistant $S$. aureus, S. aureus ATCC6538 and E. faecalis with MIC values of 0.159, 0.0794 and $0.159 \mathrm{mM}$, respectively. It appeared that compound $\mathbf{3 8}$ which was the glycosylated version of resveratrol (37) had much weaker activity than its parent, which was reported to have antibacterial activity against Streptococcus mutans and Streptococcus sanguis with MIC values of 0.219 and 0.110 $\mathrm{mM}$, respectively, but piceid (38) did not inhibit microbial growth [50]. The structures of compound 4 and 39 were quite similar, except for the position of the hydroxyl, while the activity of $\mathbf{4}$ was better than 39. They displayed inhibitory activity toward S. aureus ATCC6538 and methicillin-resistant $S$. aureus with MIC values of 0.205 and $0.409 \mathrm{mM}$, respectively. We infer that the hydroxyl position may influence antimicrobial effect, and the activity of 2,3-hydroxyl-substituted compounds was better than that of 3,4-hydroxyl-substituted compounds. The stibenolignan 36 showed antimicrobial activity against all the microorganisms tested. We suppose that the presence of a stilbene moiety in compound 36 contributes to the antimicrobial effect. 
Table 6. Minimum inhibitory concentrations (MICs, $\mathrm{mM}$ ) of the selected compounds obtained from the rhizomes of S. glabra.

\begin{tabular}{|c|c|c|c|c|c|c|c|}
\hline Compound & EC & $\mathbf{P A}$ & KP & MRSA & $\mathbf{S A}$ & EF & $\mathbf{C A}$ \\
\hline 1 & 0.604 & 0.604 & 0.604 & 0.302 & 0.302 & 0.302 & 0.146 \\
\hline 3 & $>1.21$ & $>1.21$ & $>1.21$ & 0.605 & 0.303 & 0.605 & 0.605 \\
\hline 4 & 1.64 & 1.64 & 1.64 & 0.409 & 0.205 & 0.819 & 0.819 \\
\hline 9 & $>2.10$ & $>2.10$ & $>2.10$ & 2.10 & 2.10 & $>2.10$ & $>2.10$ \\
\hline 10 & $>2.10$ & $>2.10$ & $>2.10$ & 0.524 & 0.524 & 1.05 & $>2.10$ \\
\hline 11 & $>1.33$ & $>1.33$ & $>1.33$ & $>1.33$ & $>1.33$ & $>1.33$ & $>1.33$ \\
\hline 12 & $>1.33$ & $>1.33$ & $>1.33$ & $>1.33$ & $>1.33$ & $>1.33$ & 0.666 \\
\hline 13 & $>1.33$ & $>1.33$ & $>1.33$ & 1.33 & $>1.33$ & $>1.33$ & $>1.33$ \\
\hline 14 & 1.33 & 1.33 & 1.33 & 1.33 & 0.666 & 1.33 & 1.33 \\
\hline 15 & $>1.38$ & $>1.38$ & $>1.38$ & $>1.38$ & $>1.38$ & $>1.38$ & $>1.38$ \\
\hline 16 & $>1.33$ & $>1.33$ & $>1.33$ & $>1.33$ & $>1.33$ & $>1.33$ & $>1.33$ \\
\hline 17 & $>1.33$ & $>1.33$ & $>1.33$ & 1.33 & 1.33 & 1.33 & $>1.33$ \\
\hline 20 & $>2.07$ & $>2.07$ & $>2.07$ & 1.03 & 0.517 & 1.03 & $>2.07$ \\
\hline 22 & $>1.33$ & 0.663 & $>1.33$ & 0.0801 & 0.0801 & 0.160 & 0.160 \\
\hline 33 & $>0.880$ & $>0.880$ & $>0.880$ & $>0.880$ & $>0.880$ & $>0.880$ & $>0.880$ \\
\hline 36 & 0.663 & 0.663 & 0.663 & 1.33 & 0.663 & 1.33 & 0.332 \\
\hline 37 & $>2.63$ & $>2.63$ & $>2.63$ & 0.159 & 0.0794 & 0.159 & 0.657 \\
\hline 38 & $>1.54$ & $>1.54$ & $>1.54$ & 0.768 & 0.768 & 1.54 & $>1.54$ \\
\hline 39 & 1.64 & 1.64 & 1.64 & 0.409 & 0.205 & $>1.64$ & 0.819 \\
\hline 44 & 2.52 & 2.52 & 2.52 & 0.630 & 0.630 & 1.26 & 0.630 \\
\hline 49 & 3.09 & 3.09 & 3.09 & 3.09 & 1.55 & 3.09 & 3.09 \\
\hline 51 & $>2.60$ & $>2.60$ & $>2.60$ & $>2.60$ & $>2.60$ & $>2.60$ & $>2.60$ \\
\hline Cipro & 0.00302 & 0.00302 & 0.00604 & & & & \\
\hline Van & & & & 0.000690 & 0.000690 & 0.00138 & \\
\hline Keto & & & & & & & 0.0000301 \\
\hline
\end{tabular}

EC, Escherichia coli; PA, Pseudomonas aeruginosa PA01; KP, Kiebsiella pneumonia (clinical isolate); MRSA, methicillin-resistant Staphylococcus aureus (clinical isolate); SA, Staphylococcus aureus ATCC6538; EF, Enterococcus faecalis; CA, Canidia albicans SC5314; Cipro, ciprofloxacin; Van, vancomycin; Keto, ketoconazole.

\section{Experimental}

\subsection{General}

Optical rotations were measured with a Rudolph Research Analytical Autopol IV Automatic Polarimeter. IR spectra were recorded on a Thermo Nicolet Nexus 470 FT-IR spectrophotometer with $\mathrm{KBr}$ pellets. UV spectra were recorded on a Varian Cary Eclipse 300 spectrometer. 1D and 2D NMR experiments were performed on a Varian INOVA 500 or Bruker DRX 400 or 600 spectrometers with tetramethylsilane (TMS) as internal reference, and chemical shifts were expressed in $\delta$ (ppm). HR-ESI-MS and HR-EI-MS data were obtained on a Shimadzu LCMS-IT-TOF mass spectrometer and a Bruker Daltonics APEXII FT-ICR mass spectrometer, respectively. Column chromatography was performed on silica gel (100-200 mesh, 200-300 mesh, Qingdao Marine Chemical Inc., Qingdao, China), 
Sephadex LH-20 (Amersham Pharmacia Biotech Ltd., Beijing, China), Toyopearl HW-40 (Amersham Pharmacia Biotech Ltd., Beijing, China), macroporous resin D101 (Cangzhou Baoen Adsorptive Material Technology Co., Ltd., Hebei, China) and RP-C 18 (Daiso, Osaka, Japan). TLC was performed with glass precoated silica gel $\mathrm{GF}_{245}$ plates (Qingdao Marine Chemical Inc., Qingdao, China). MPLC was performed using a Lisui EZ Purify III System including pump manager P03, detector modules P02, and fraction collector P01 (Shanghai Li Sui Chemical Engineering Co., Ltd., Shanghai, China) and columns packed with RP-18 silica gel (Merck, Darmstadt, Germany). Semi-preparative high performance liquid chromatography was carried out on an Agilent 1200 system equipped with a diode array detector working in the range of 190-500 nm. Samples were separated on a Zorbax SB-C 18 $(250 \mathrm{~mm} \times 9.4 \mathrm{~mm}, 5 \mu \mathrm{m}$, Agilent $)$ column .

\subsection{Plant Material}

Two batches of the dried sliced rhizomes of Smilax glabra Roxb. were purchased from Beijing Ben Cao Fang Yuan Pharmaceutical Co. Ltd. (Beijing, China) in May 2009 and December 2011, respectively, and were identified by Prof. Shao-Qing Cai (State Key Laboratory of Natural and Biomimetic Drugs, School of Pharmaceutical Sciences, Peking University, Beijing, China). The voucher specimens (No.6176 and No.6836) were deposited in the Herbarium of Pharmacognosy, School of Pharmaceutical Sciences, Peking University (Beijing, China).

\subsection{Extraction and Isolation}

The air-dried and powdered rhizomes of $S$. glabra $(20 \mathrm{~kg}$, No.6176) were extracted three times with $95 \%$ ethanol $(120 \mathrm{~L}, 100 \mathrm{~L}, 100 \mathrm{~L})$ and $50 \%$ ethanol $(100 \mathrm{~L} \times 3)$ under reflux, respectively. After evaporation of the combined extracts, the residue $(2,552 \mathrm{~g})$ was suspended in $10 \mathrm{~L}$ of water, and then partitioned successively with petroleum ether $(10 \mathrm{~L} \times 4)$, ethyl acetate (EtOAc, $10 \mathrm{~L} \times 4)$, and $n$-butanol $(n-\mathrm{BuOH}, 10 \mathrm{~L} \times 4)$ to afford the corresponding petroleum-ether-soluble, EtOAc-soluble, and $n-\mathrm{BuOH}$-soluble fractions after concentration of the solutiond under vacuum. The ethyl acetate extract (140 g) was subjected to silica gel (200-300 mesh, $2300 \mathrm{~g}$ ) column chromatography and eluted with a gradient of $\mathrm{CHCl}_{3}-\mathrm{MeOH}(20: 1-0: 1, \mathrm{v} / \mathrm{v})$ to give 13 fractions TE1-TE13. Fraction TE2 (6.5 g) was applied to a silica gel (200-300 mesh, $150 \mathrm{~g})$ column using a gradient of petroleum ether-acetone $(80: 1-1: 4, \mathrm{v} / \mathrm{v})$ to get the corresponding subfractions. Compounds 63 (3.5 mg), 57 (328 mg), 56 (16.1 mg), 5 (4.5 mg), 48 (1.1 mg), $55(4.4 \mathrm{mg})$ and $\mathbf{8}(30.8 \mathrm{mg})$ were obtained from TE2 by silica gel column chromatography combined with semipreparative HPLC $\left(\mathrm{CH}_{3} \mathrm{CN}-\mathrm{H}_{2} \mathrm{O}\right.$ gradient elution). Fraction TE3 (9.5 g) was subjected to a silica gel (200-300 mesh, $300 \mathrm{~g})$ column eluting with a gradient of petroleum ether-acetone (40:1-1:4, v/v) to give nine subfractions (E3-1-E3-9). E3-4 and E3-6 were then separated by semipreparative HPLC $\left(\mathrm{CH}_{3} \mathrm{CN}-\mathrm{H}_{2} \mathrm{O}\right.$ gradient elution) to afford 46 (4.0 mg), 3 (10.2 mg) and 32 (5.3 mg). Subfraction E3-8 was subjected to a Sephadex LH-20 column $(2.5 \times 57 \mathrm{~cm})$ eluting with $\mathrm{CHCl}_{3}-\mathrm{MeOH}(1: 1, \mathrm{v} / \mathrm{v})$ and was further purified by semipreparative HPLC to yield 10 (5 mg). Fraction TE4 (7.5 g) was chromatographed on a silica gel (200-300 mesh, $230 \mathrm{~g})$ column using a gradient of petroleum ether-acetone $(6: 1-1: 4, \mathrm{v} / \mathrm{v})$ to get subfractions. Compounds 49 (2.4 mg), 31 (3.9 mg) and $\mathbf{9}(19.3 \mathrm{mg})$ were isolated from TE4 using MPLC (ODS column) and semipreparative HPLC $\left(\mathrm{CH}_{3} \mathrm{CN}-\mathrm{H}_{2} \mathrm{O}\right.$ gradient elution). Compound $38(8.1 \mathrm{mg})$ was obtained by 
recrystallization. Compound $37(2.3123 \mathrm{~g})$ was obtained from fraction TE5 (6.6 g) using recrystallization, while the remaining portion was subjected to a silica gel (200-300 mesh, $190 \mathrm{~g}$ ) column eluting with a gradient of $\mathrm{CHCl}_{3}-\mathrm{MeOH}(30: 1-1: 2$, v/v) to give 12 subfractions (E5-1-E5-12). Compounds 6 (2.3 mg), $33(13.8 \mathrm{mg})$ and $34(1.9 \mathrm{mg})$ were obtained from TE5 through Sephadex LH-20 column chromatography and reverse-phase semipreparative HPLC. Compound 58 (106.4 mg) was obtained from fraction TE6 $(5.7 \mathrm{~g})$. The remaining portion of TE6 was subjected to a silica gel (200-300 mesh, $170 \mathrm{~g}$ ) column eluting with a gradient of $\mathrm{CHCl}_{3}-\mathrm{MeOH}(40: 1-0: 1, \mathrm{v} / \mathrm{v})$ and then purified by semipreparative HPLC to yield $24(12.7 \mathrm{mg})$. Fraction TE7 $(6.7 \mathrm{~g})$ was separated on a silica gel (200-300 mesh, $260 \mathrm{~g})$ column eluting with a gradient of cyclohexane-acetone $(3: 1-0: 1, \mathrm{v} / \mathrm{v})$ to obtain 11 subfractions (E7-1-E7-11). Compounds 7 (22.3 mg), 21 (25.4 mg) and 59 (3.1 mg) were obtained from TE7 by repeated Sephadex LH-20 chromatography and MPLC. Fraction TE8 (10.7 g) was subjected to a silica gel (200-300 mesh, $270 \mathrm{~g})$ column eluting with a gradient of $\mathrm{CHCl}_{3}-\mathrm{MeOH}$ $(10: 1-0: 1, \mathrm{v} / \mathrm{v})$ to give eight subfractions (E8-1-E8-8). Subfraction E8-6 was separated on a silica gel (200-300 mesh, $50 \mathrm{~g})$ column and eluted with a gradient of $\mathrm{CHCl}_{3}-\mathrm{MeOH}-\mathrm{H}_{2} \mathrm{O}(7: 1: 0.1-1: 1: 0.1$, v/v/v) to afford 20 (36.6 mg). Compound 11 (2.0265 g) was obtained from fraction TE9 (35 g), while the remaining portion was applied to a silica gel (200-300 mesh, 700 g) column eluting with a gradient of $\mathrm{CHCl}_{3}-\mathrm{MeOH}(6: 1-1: 2, \mathrm{v} / \mathrm{v})$ to yield 12 (9.1454 g). The obtained subfractions were separated by repeated Sephadex LH-20, Toyopearl HW-40 column chromatography and further separated by semipreparative HPLC to yield $\mathbf{1 3}(85.1 \mathrm{mg}), \mathbf{1 4}(18.3 \mathrm{mg}), \mathbf{1 5}(19.7 \mathrm{mg})$ and $\mathbf{1 6}(7.6 \mathrm{mg})$. Fraction TE11 (10.1 g) was subjected to a silica gel (200-300 mesh, $290 \mathrm{~g})$ column eluting with a gradient of cyclohexane-acetone (2:1-0:1, v/v) and further separated by semipreparative HPLC to yield 47 (15.8 mg).

The $n$-butanol extract (183.9 g) was dissolved in water and passed through a column of D101 macroporous adsorptive resin (4 L) with water, $10 \%, 20 \%, 30 \%, 40 \%, 60 \%, 80 \%, 95 \% \mathrm{EtOH}$ as eluents, respectively, to afford eight fractions TB1-TB8. Fraction TB2 was separated using MPLC (ODS column, $\mathrm{CH}_{3} \mathrm{CN}-\mathrm{H}_{2} \mathrm{O}$ gradient elution). The obtained subfractions were submitted to Sephadex LH-20 column chromatography and further separated by semipreparative HPLC $\left(\mathrm{CH}_{3} \mathrm{CN}-0.1 \%\right.$ TFA gradient elution) to yield $\mathbf{5 0}(104.6 \mathrm{mg}), \mathbf{6 1}(8.4 \mathrm{mg})$ and $\mathbf{5 3}(8.3 \mathrm{mg})$. Fraction TB4 was subjected to Sephadex LH-20, Toyopearl HW-40 column repeatedly and was further separated by semipreparative HPLC to yield 19 (3 mg), 41 (9 mg), 18 (3 mg) and 17 (6.4 mg).

The second batch of crude drug, air-dried and powdered rhizomes of S. glabra (42 kg, No. 6836) were extracted and isolated. The extraction method was the same as for the first batch. The ethyl acetate extract (282 g) was applied to a silica gel (100-200 mesh, $4970 \mathrm{~g})$ column and eluted with a gradient of $\mathrm{CHCl}_{3}-\mathrm{MeOH}(30: 1-0: 1, \mathrm{v} / \mathrm{v})$ to give 17 fractions GE1-GE17. Fraction GE5 (8 g) was separated on Sephadex LH-20 column $(2.7 \times 62 \mathrm{~cm})$ repeatedly with $\mathrm{CHCl}_{3}-\mathrm{MeOH}(1: 1, \mathrm{v} / \mathrm{v})$ as eluent to give the corresponding subfractions, which were repeatedly subjected to Sephadex LH-20 column chromatography and further purified by semipreparative HPLC $\left(\mathrm{CH}_{3} \mathrm{CN}-0.03 \%\right.$ TFA gradient elution) to afford $\mathbf{5 1}(30.2 \mathrm{mg}), \mathbf{4 0}(28.4 \mathrm{mg}), \mathbf{2 9}(6 \mathrm{mg}), \mathbf{5 2}(6 \mathrm{mg}), \mathbf{2 8}(3.1 \mathrm{mg})$ and $\mathbf{3 6}$ (4.5 mg). Fraction GE6 $(7.1 \mathrm{~g})$ was sunjected to repeated Sephadex LH-20, Toyopearl HW-40 column chromatography and further separated via semipreparative HPLC to get $\mathbf{5 4}(6.5 \mathrm{mg}), \mathbf{6 0}(1.9 \mathrm{mg})$ and $\mathbf{4 3}(2 \mathrm{mg})$. Fraction GE8 (3 g) and GE9 (4.5 g) were treated by the similar method as GE6 to yield 25 (14.5 $\mathrm{mg}), 26$ (3.1 mg), $44(6 \mathrm{mg}), \mathbf{4 5}(4 \mathrm{mg}), \mathbf{3 5}(5.7 \mathrm{mg}), \mathbf{4}(21.1 \mathrm{mg})$ and $\mathbf{3 0}(5 \mathrm{mg})$. Fraction GE10 (5 g) was repeatedly submitted to Sephadex LH-20 column chromatography and further purified by 
semipreparative HPLC to afford $42(1.7 \mathrm{mg}), \mathbf{1}(4.4 \mathrm{mg}), \mathbf{2}(2.5 \mathrm{mg}), \mathbf{3 9}(24.5 \mathrm{mg})$ and 27 (2 $\mathrm{mg})$, while GE12 (5 g) was separated using the similar method as GE10 to yield $22(8.3 \mathrm{mg})$ and $\mathbf{2 3}(2.8 \mathrm{mg})$.

\subsection{Spectroscopic Data}

Smiglabrone $A$ (1). Pale yellow solid; mp $175-177{ }^{\circ} \mathrm{C}$; $[\alpha]_{\mathrm{D}}^{20} 63.6(c 0.44, \mathrm{MeOH})$; CD $\left(2.72 \times 10^{-4}\right.$ $\mathrm{MeOH}): \Delta \varepsilon(\mathrm{nm}) 0.49$ (214), -14.46 (235), 0.41 (259), -4.77 (284); UV $\lambda_{\max }(\mathrm{MeOH}): 202,230,280$ $\mathrm{nm}$; IR (KBr) $v_{\max }\left(\mathrm{cm}^{-1}\right): 3,452,2,920,2,850,1,751,1,676,1,620,1,520,1,466,1,368,1,278,1,202$, 1,161, 1,112, 1,064, 997, 834, 724; HR-ESI-MS m/z: $495.1299[\mathrm{M}-\mathrm{H}]^{-}$(calcd. for $\mathrm{C}_{26} \mathrm{H}_{23} \mathrm{O}_{10}$ 495.1291); ${ }^{1} \mathrm{H}$ - and ${ }^{13} \mathrm{C}-\mathrm{NMR}$ spectroscopic data see Table 1.

Smiglabrone B (2). Pale yellow solid; mp 172-174 ${ }^{\circ} \mathrm{C}$; $[\alpha]_{\mathrm{D}}^{20}-80.0(c 0.20, \mathrm{MeOH}) ; \mathrm{CD}\left(4.60 \times 10^{-4}\right.$ $\mathrm{MeOH}): \Delta \varepsilon$ (nm) 2.02 (214), -18.04 (234), 1.29 (256), -4.84 (284); UV $\lambda_{\max }(\mathrm{MeOH}): 202,230,280$ $\mathrm{nm}$; IR (KBr) $v_{\max }\left(\mathrm{cm}^{-1}\right): 3,453,2,921,2,853,1,745,1,629,1,542,1,458,1,261,1,165,1,112,894$, 802; HR-ESI-MS m/z: $465.1189[\mathrm{M}-\mathrm{H}]^{-}$(calcd. for $\mathrm{C}_{25} \mathrm{H}_{21} \mathrm{O}_{9} 465.1186$ ), $467.1327[\mathrm{M}+\mathrm{H}]^{+}$(calcd. for $\left.\mathrm{C}_{25} \mathrm{H}_{23} \mathrm{O}_{9} 467.1342\right) ;{ }^{1} \mathrm{H}$ - and ${ }^{13} \mathrm{C}$-NMR spectroscopic data see Table 1.

Smilachromanone (3). Pale yellow solid; mp 81-83 ${ }^{\circ} \mathrm{C}$; $[\alpha]_{\mathrm{D}}^{20}+178.72(c$ 0.47, MeOH); CD (1.94 $\times$ $\left.10^{-4} \mathrm{MeOH}\right): \Delta \varepsilon(\mathrm{nm})+13.43(260),+6.22$ (312), -29.23 (290); UV $\lambda_{\max }(\mathrm{MeOH}): 216,294 \mathrm{~nm}$; IR $(\mathrm{KBr}) v_{\max }\left(\mathrm{cm}^{-1}\right): 3,450,2,921,1,633,1,436,1,376,1,314,1,243,1,165,1,058,897,795$; HR-ESI-MS m/z: 329.1033 [M-H] ${ }^{-}$(calcd. for $\mathrm{C}_{18} \mathrm{H}_{17} \mathrm{O}_{6}$ 329.1025); ${ }^{1} \mathrm{H}-$ and ${ }^{13} \mathrm{C}-\mathrm{NMR}$ spectroscopic data see Table 2.

Smiglastilbene (4). Brown-yellow powder; mp 179-181 ${ }^{\circ} \mathrm{C}$; UV $\lambda_{\max }(\mathrm{MeOH}): 220,306 \mathrm{~nm}$; IR (KBr) $v_{\max }\left(\mathrm{cm}^{-1}\right): 3,449,1,674,1,595,1,475,1,382,1,346,1,275,1,201,1,160,996,832 ; \mathrm{HR}-\mathrm{ESI}-\mathrm{MS} \mathrm{m} / \mathrm{z}$ : 243.0659 [M-H] ${ }^{-}$(calcd. for $\mathrm{C}_{14} \mathrm{H}_{11} \mathrm{O}_{4}$ 243.0657); ${ }^{1} \mathrm{H}$ - and ${ }^{13} \mathrm{C}-\mathrm{NMR}$ spectroscopic data see Table 3.

Smiglactone (5). White powder; $\mathrm{mp} 88-90{ }^{\circ} \mathrm{C} ;[\alpha]_{\mathrm{D}}^{20}+120(c 0.1, \mathrm{MeOH}) ; \mathrm{CD}\left(8.06 \times 10^{-4} \mathrm{MeOH}\right): \Delta \varepsilon$ $(\mathrm{nm})+34.11$ (214), -10.21 (298); UV $\lambda_{\max }(\mathrm{MeOH}): 201,289 \mathrm{~nm}$; IR (KBr) $v_{\max }\left(\mathrm{cm}^{-1}\right): 3,357,1,747$, 1,592, 1,489, 1,466, 1,373, 1,321, 1,279, 1,219, 1,160, 1,081, 1,049, 983, 817, 702; HR-EI-MS m/z: $248.1415[\mathrm{M}]^{+}$(calcd. for $\mathrm{C}_{15} \mathrm{H}_{20} \mathrm{O}_{3} 248.1412$ ); ${ }^{1} \mathrm{H}$ - and ${ }^{13} \mathrm{C}-\mathrm{NMR}$ spectroscopic data see Table 4.

Smiglabrol (6). Pale yellow solid; mp $128-130{ }^{\circ} \mathrm{C}$; $[\alpha]_{\mathrm{D}}^{20}-156.5(c 0.08, \mathrm{MeOH})$; UV $\lambda_{\max }(\mathrm{MeOH})$ : 206, 225, 278nm; IR (KBr) $v_{\max }\left(\mathrm{cm}^{-1}\right): 3,360,2,927,1,678,1,611,1,515,1,455,1,378,1,341,1,303$, 1,245, 1,158, 1,092, 1,058, 1,007, 923, 838, 718, 695; HR-ESI-MS m/z: $311.06917[\mathrm{M}+\mathrm{Cl}]^{-}$, $338.08813\left[\mathrm{M}+\mathrm{NO}_{3}\right]^{-}, \quad 587.16893[2 \mathrm{M}+\mathrm{Cl}]^{-}$(calcd. for $\mathrm{C}_{15} \mathrm{H}_{16} \mathrm{O}_{5} \mathrm{Cl}$ 311.06921, $\mathrm{C}_{15} \mathrm{H}_{16} \mathrm{O}_{5} \mathrm{NO}_{3}$ 338.08835, $\mathrm{C}_{30} \mathrm{H}_{32} \mathrm{O}_{10} \mathrm{Cl}$ 587.16829, respectively); ${ }^{1} \mathrm{H}$ - and ${ }^{13} \mathrm{C}$-NMR spectroscopic data see Table 5.

\subsection{Antimicrobial Assay}

The screening for in vitro antibacterial activity was performed according to the Antimicrobial Susceptibility Testing Standards outlined by the Clinical and Laboratory Standards Institute (CLSI, formerly NCCLS) [51]. The microorganisms used were: E. coli, P. aeruginosa PA01, K. pneumonia, methicillin-resistant $S$. aureus and $S$. aureus ATCC6538, Enterococcus faecalis. Vancomycin was used 
as positive control drug for methicillin-resistant S. aureus, S. aureus ATCC6538 and E. faecalis assay, and ciprofloxacin for P. aeruginosa PA01, E. coli and K. pneumonia assay. MIC (minimal inhibition concentration) here is defined as the lowest concentration of compound that results in inhibition of visible bacterial growth (no turbidity) compared with the positive control antibiotics. All tests were performed in triplicate. Canidia albicans SC5314 was used as a test strain for antifungal bioassay. The experiments were carried out using a broth microdilution protocol modified from the Clinical and Laboratory Standards Institute M-27A methods [52]. The antifungal positive control was ketoconazole and antifungal MICs were determined by measuring and comparing the optical diversities of the blank control and tested wells. All tests were performed in triplicate.

\section{Conclusions}

In this study, six new phenolic compounds 1-6, together with fifty-seven known compounds 7-63, were isolated and identified from the rhizomes of $S$. glabra. Twenty-seven of these compounds 10, 17, 26-36, 42, 43, 45, 46, 48-50, 52-55, 60-62 have never been reported from the genus Smilax before. In addition, this is the first report of the presence of the homoisoflavanone $\mathbf{3}$, chalcone $\mathbf{2 8}$, aurones $\mathbf{2 9}, \mathbf{3 0}$ and stibenolignans 35, 36 in this genus. The antimicrobial results revealed the effective constituents of this crude drug for clinical use. The structure types, stereo configuration and substituent groups appeared to be important structural factors that determined their antimicrobial properties. The stereochemistry at C2 and C3 of flavan-3-ols and flavanones largely govern the potency of antimicrobial activity. In addition, hydroxylation at position 3 of the $\mathrm{C}$ ring is essential for the activity of flavanones. It appeared that the glycosylation at position 3 of resveratrol resulted in the remarkable decrease of the antimicrobial effect. Our research revealed that the three stilbenes $(4,37,39)$, two flavan-3-ols $(\mathbf{1}, \mathbf{2 2})$, one homoisoflavanone (3), one phenylpropanoid (44) and one stilbenolignan (36) present in the crude extract displayed better antimicrobial activity than the other investigated compounds. The lack of potency in some of the compounds isolated in this study appears to reinforce the view that herbal drug extracts may be superior to single constituents due to synergistic effects. Further studies are warranted to reveal the mechanisms of the active compounds found in S. glabra rhizomes underlying their antimicrobial properties.

\section{Supplementary Materials}

Supplementary materials can be accessed at: http://www.mdpi.com/1420-3049/18/5/52658/s1.

\section{Acknowledgments}

This work was supported by National Key Technology R\&D Program "New Drug Innovation" of China (No. 2013ZX09508104). We also wish to thank Huan-Qin Dai, from Key Laboratory of Pathogenic Microbiology and Immunology, Institute of Microbiology Chinese Academy of Sciences, for assistance with running the antimicrobial assay.

\section{Conflict of Interest}

The authors declare no conflict of interest. 


\section{References}

1. Wang, F.Z.; Tang, J; Chen, X.Q.; Zhang, Z.Y.; Dai, L.K.; Liang, S.J.; Tang, Y.C.; Liu, L.; Lang, K.Y. Flora Reipublicae Popularis Sinicae, 1st ed.; Science Press: Beijing, China, 1978; Volume 15, pp. 212-214.

2. Song, L.; Wu, Y.; Hu, L.; Zhang, G.; Xu, G.; Xiao, P.; Ling, Y.; Ding, X.; Cao, C.; Li, Y. Zhong Hua Ben Cao; Shanghai Science and Technology Publisher: Shanghai, China, 1999; Volume 22, pp. 161-164.

3. Pharmacopoeia Commission of PRC. In Pharmacopoeia of the People's Republic of China; Chinese Medicine Science and Technology Press: Beijing, China, 2010; Volume I, p. 17.

4. Gao, Y.J.; Su, Y.H.; Qu, L.K.; Xu, S.; Meng, L.; Cai, S.Q.; Shou, C.C. Mitochondrial apoptosis contributes to the anti-cancer effect of Smilax glabra Roxb. Toxicol. Lett. 2011, 207, 112-120.

5. Zhang, Q.F.; Zhang, Z.R.; Cheung, H.Y. Antioxidant activity of Rhizoma Smilacis Glabrae extracts and its key constituent-astilbin. Food Chem. 2009, 115, 297-303.

6. Ji, L.L.; Fan, Y.M. Antibacterial activity of extracts from Smilax glabra. Life Sci. Res. 2002, 6, 84-87.

7. Kuspradini, H.; Mitsunaga, T.; Ohashi, H. Antimicrobial activity against Streptococcus sobrinus and glucosyltransferase inhibitory activity of taxifolin and some flavanonol rhamnosides from kempas (Koompassia malaccensis) extracts. J. Wood Sci. 2009, 55, 308-313.

8. Chen, L.; Yin, Y.; Yi, H.W.; Xu, Q.; Chen, T. Simultaneous quantification of five major bioactive flavonoids in Rhizoma Smilacis Glabrae by high-performance liquid chromatography. J. Pharmaceut. Biomed. 2007, 43, 1715-1720.

9. You, J.G. Summary on clinical application of the rhizomes of Smilax glabra Roxb. Fujian J. Tradit. Chin. Med. 2002, 33, 50-51.

10. Ao, C.W.; Higa, T.; Khanh, T.D.; Upadhyay, A.; Tawata, S. Antioxidant phenolic compounds from Smilax sebeana Miq. Food Sci. Technol. 2011, 44, 1681-1686.

11. Ming, D.S.; López, A.; Hillhouse, B.J.; French, C.J.; Hudson, J.B.; Towers, G.H.N. Bioactive constituents from Iryanthera megistophylla. J. Nat. Prod. 2002, 65, 1412-1416.

12. Foo, L.Y. Phenylpropanoid derivatives of catechin, epicatechin and phylloflavan from Phyllocladus trichomanoides. Phytochemistry 1987, 26, 2825-2830.

13. Nonaka, G.I.; Nishioka, I. Tannins and related compounds VII phenylpropanoid-substituted epicatechin, cinchonains from Cinchona succirubra. Chem. Pharm. Bull. 1982, 30, 4268-4276.

14. Watanabe, Y.; Sanada, S.; Ida, Y.; Shoji, J. Comparative studies on the constituents of Ophiopogonis tuber and its congenes. IV. Studies on the homoisoflavonoids of the subterranean part of Ophiopogon ohwii OKUYAMA and O. jaburan (KUNTH) LODD. Chem. Pharm. Bull. 1985, 33, 5358-5363.

15. Tang, Y.P.; Yu, B.; Hu, J.; Wu, T.; Hui, H.Z. Three new homoisoflavanone glycosides from the bulbs of Ornithogalum caudatum. J. Nat. Prod. 2002, 65, 218-220.

16. Spassov, S.L. Nuclear magnetic resonance spectra, configuration and conformation of diastereomers: 3-substituted 2,3-diphenylpropanoic acids and their methyl esters. Tetrahedron 1969, 25, 3631-3638. 
17. Yuan, Z.; Li, X. NMR methods for determining the configuration of 8-O-4' neolignans. Chin. J. Mag. Reson. 2003, 20, 307-314.

18. Koshino, H.; Terada, S.; Yoshihara, T.; Sakamura, S.; Shimanuki, T.; Sato, T.; Tajimi, A. Three phenolic acid derivatives from stromata of Epichloe typhina on Phleum pretense. Phytochemistry 1988, 27, 1333-1338.

19. Berova, N.; Nakanishi, K. Circular Dichroism: Principles and Applications, 2nd ed.; Wiley-VCH: New York, NY, USA, 2000; pp. 337-382.

20. Adam, W.; Humpf, H.U.; Korb, M.N.; Schreier, P. The configurational assignment of the optically active 5-(1-hydro-peroxyethyl)-3-ethoxycarbonyl-2-methylfuran and its alcohol by exciton-coupled circular dichroism (ECCD). Tetrahedron Asymmetr. 1997, 8, 3555-3558.

21. Wungsintaweekul, B.; Umehara, K.; Miyase, T.; Noguchi H. Estrogenic and anti-estrogenic compounds from the Thai medicinal plant, Smilax corbularia (Smilacaceae). Phytochemistry 2011, 72, 495-502.

22. Zhang, X.F.; Hung, T.M.; Phuong, P.T.; Ngoc, T.M.; Min, B.S.; Song, K.S.; Seong, Y.H.; Bae, K. Anti-inflammatory activity of flavonoids from Populus davidiana. Arch. Pharm. Res. 2006, 29, 1102-1108.

23. Kasai, R.; Hirono, S.; Chou, W.H.; Tanaka, O.; Chen, F.H. Sweet dihydroflavonol rhamnoside from leaves of Engelhardtia chrysolepis, a Chinese folk medicine, Hung-qi. Chem. Pharm. Bull. 1988, 36, 4167-4170.

24. Kang, J; Xie, C.H.; Li, Z.M.; Nagarajan, S; Schauss, A.G.; Wu, T.; Wu, X.L. Flavonoids from acai (Euterpe oleracea Mart.) pulp and their antioxidant and anti-inflammatory activities. Food Chem. 2011, 128, 152-157.

25. Si, C.L.; Wu, L.; Zhu, Z.Y. Phenolic glycosides from Populus davidiana bark. Biochem. Syst. Ecol. 2009, 37, 221-224.

26. Dübeler, A.; Voltmer, G.; Gora, V.; Lunderstädt, J.; Zeeck A. Phenols from Fagus sylvatica and their role in defense against Cryptococcus fagisuga. Phytochemistry 1997, 45, 51-57.

27. Dominguez, X.A.; Garcia, S., Williams, H.J.; Ortiz, C.; Scott, A.N.; Beibenspies, J.H. Kukulkanins A and B, new chalcones from Mimosa tenuefolia. J. Nat. Prod. 1989, 52, 864-867.

28. Haudecoeur, R.; Ahmed-Belkacem, A.; Yi, W.; Fortune, A.; Brillet, R.; Belle, C.; Nicolle, E.; Pallier, C.; Pawlotsky, J.M.; Boumendjel, A. Discovery of naturally occur ring aurones that are potent allosteric inhibitors of hepatitis $\mathrm{C}$ virus RNA-dependent RNA polymerase. $J$. Med. Chem. 2011, 54, 5395-5402.

29. Detsi, A.; Majdalani, M.; Kontogiorgis, C.A.; Hadjipavlou-Litina, D.; Kefalas, P. Natural and synthetic 2'-hydroxy-chalcones and aurones: Synthesis, characterization and evaluation of the antioxidant and soybean lipoxygenase inhibitory activity. Bioorgan. Med. Chem. 2009, 17, 8073-8085.

30. Achenbach, H.; Waibel, R.; Addae-mansah, I. Lignans and other constituents from Carissa edulis. Phytochemistry 1983, 22, 749-753.

31. Otsuka, H.; Takeuchi, M.; Inoshiri, S.; Sato, T.; Yamasaki, K. Phenolic compounds from Coix lachryma-jobi var. Ma-Yuen. Phytochemistry 1989, 28, 883-886.

32. Freudenberg, K.; Schraube, H. Sinapyl alcohol and the synthesis of syringaresinol. Chemische. Berichte. 1955, 88, 16-23. 
33. Li, L.Y.; Seeram, N.P. Maple syrup phytochemicals include lignans, coumarins, a stilbene, and other previously unreported antioxidant phenolic compounds. J. Agric. Food Chem. 2010, 58, 11673-11679.

34. Kobayashi, M.; Mahmud. T.; Yoshioka, N.; Hori, K.; Shibuya, H.; Kitagawa, I. Indonesian medicinal plants. XVIII. Kompasinol A, a new stibeno-phenylpropanoid from the bark of Koompassia malaccensis (Fabaceae). Chem. Pharm. Bull. 1996, 44, 2249-2253.

35. Lee, D.; Cuendet, M.; Vigo, J.S.; Graham, J.G.; Cabieses, F.; Fong, H.H.S.; Pezzuto, J.M.; Kinghorn, A.D. A novel cyclooxygenase-inhibitory stilbenolignan from the seeds of Aiphanes aculeata. Org. Lett. 2001, 3, 2169-2171.

36. Ha, D.T.; Chen, Q.C.; Hung, T.M.; Ui, J.Y.; Ngoc, T.M.; Thuong, P.T.; Kim, H.J.; Seong, Y.H.; Min, B.S.; Bae, K.H. Stilbenes and oligostilbenes from leaf and stem of Vitis amurensis and their cytotoxic activity. Arch. Pharm. Res. 2009, 32, 177-183.

37. Adam, K.P. Phenolic constituents of the fern Phegopteris connectilis. Phytochemistry 1999, 52, 929-934.

38. Jin, D.Z.; Min, Z.D.; Chiou, G.C.Y.; Linuma, M.; Tanaka, T. Two $p$-coumaroyl glycerides from Juncus Effusus. Phytochemistry 1996, 41, 545-547.

39. Luo, J.G.; Li, L.; Kong, L.Y. Preparative separation of phenylpropenoid glycerides from the bulbs of Lilium lancifolium by high-speed counter-current chromatography and evaluation of their antioxidant activities. Food Chem. 2012, 131, 1056-1062.

40. Fabrice, V.; Michel, G. Enantiomeric purity of scytalone from different fungai sources. Tetrahedron 1990, 46, 2827-2834.

41. Limasset, B.; Doucen, C.; Dore, J.C.; Ojasoo, T.; Damon, M.; de Paulet, A.C. Effects of flavonoids on the release of reactive oxygen species by stimulated human neutrophils. Multivariate analysis of structure-activity relationships (SAR). Biochem. Pharmacol. 1993, 46, 1257-1271.

42. Satomi, Y. Inhibitory effects of 3'-methyl-3-hydroxy-rchalcone on proliferation of human malignant tumor cells and on skin carcinogenesis. Int. J. Cancer 1993, 55, 506-514.

43. Lam, S.H.; Chen, J.M.; Kang, C.J.; Chen, C.H.; Lee, S.S. $\alpha$-Glucosidase inhibitors from the seeds of Syagrus romanzoffiana. Phytochemistry 2008, 69, 1173-1178.

44. Zhou, J.; Qu, J.; Shou, G.X.; Lü, S.H. Determination of astilbin and engeletin in Smilax glabra Roxb. by RP-HPLC. Drug Stand. Chin. 2009, 10, 372-373.

45. Yuan, J.Z.; Dou, D.Q.; Chen, Y.J.; Li, W.; Kazuo, K.; Tamotsu, N.; Yao, X.S. Studies on dihydroflavonol glycosides from rhizome of Smilax glabra. Chin. J. Chin. Mater. Med. 2004, 29, 867-870.

46. Yi, Y.J.; Cao, Z.Z.; Yang, D.L.; Cao, Y.; Wu, Y.P.; Zhao, S.X. Studies on the chemical constituents of Smilax glabra. Acta Pharm. Sin. 1998, 33, 873-875.

47. Chen, G.Y.; Shen, L.S.; Jiang, P.F. Studies on flavanonol glucosides of Smilax glabra Roxb. Chin. J. Chin. Mater. Med. 1996, 21, 355-357.

48. Wu, B.; Ma, Y.P.; Yuan, J.Z.; Sun, Q.S. Isolation and identification of chemical constituents from rhizomes of Smilax glabra Roxb. J. Shenyang Pharm. Univ. 2010, 27, 116-119.

49. Zhang, M.; Li, H.T.; Li, Y. Studies on the chemical constituents of Smilax glabra. Chin. Med. Mat. 1995, 18, 191-193. 
50. Yim, N.H.; Ha, D.T.; Trung, T.N.; Kim, J.P.; Lee, S.M.; Na, M.K.; Jung, H.J.; Kim, H.S.; Kim, Y.H.; Bae, K.H. The antimicrobial activity of compounds from the leaf and stem of Vitis amurensis against two oral pathogens. Bioorg. Med. Chem. Lett. 2010, 20, 1165-1168.

51. National Committee for Clinical Laboratory Standard. Methods for dilution antimicrobial susceptibility tests for bacteria that grow aerobically. In Approved standard. NCCLS Document M7-A6, 6th ed.; NCCLS: Wayne, USA, 2003; Volume 23, pp. 1-50.

52. National Committee for Clinical Laboratory Standards. Reference method for broth dilution antifungal susceptibility testing of yeasts. In Approved Standard. NCCLS Document M27-A2, 2nd ed.; NCCLS: Pennsylvania, USA, 2002; Volume 22, pp. 1-29.

Sample Availability: Samples of the compounds 1-63 are available from the authors.

(C) 2013 by the authors; licensee MDPI, Basel, Switzerland. This article is an open access article distributed under the terms and conditions of the Creative Commons Attribution license (http://creativecommons.org/licenses/by/3.0/). 